\title{
Neoliberalism and Social Resilience in the Developed Democracies
}

\section{Citation}

Barnes, Lucy, and Peter A. Hall. "Neo-Liberalism and Social Resilience in the Developed Democracies." In Social Resilience in the Neo-Liberal Era. New York, NY: Cambridge University Press, 2013. doi: 10.1017/CB09781139542425.013

\section{Published Version}

doi:10.1017/CB09781139542425.013

\section{Permanent link}

http://nrs.harvard.edu/urn-3:HUL.InstRepos:34298831

\section{Terms of Use}

This article was downloaded from Harvard University's DASH repository, and is made available under the terms and conditions applicable to Open Access Policy Articles, as set forth at http:// nrs.harvard.edu/urn-3:HUL.InstRepos:dash.current.terms-of-use\#OAP

\section{Share Your Story}

The Harvard community has made this article openly available.

Please share how this access benefits you. Submit a story.

Accessibility 


\title{
Neo-Liberalism and Social Resilience in the Developed Democracies
}

\author{
Lucy Barnes and Peter A. Hall
}

Nuffield College, Oxford

Harvard University

June 2012

Minda de Gunzburg Center for European Studies

Harvard University

27 Kirkland Street

Cambridge MA 02138

Forthcoming in Peter A. Hall and Michèle Lamont, eds. Social Resilience in the NeoLiberal Era. (New York: Cambridge University Press). 
History flows in streams that overlap and sometimes shift direction. From the early 1980s, just such a shift was discernible in the history of the developed democracies. For thirty years after World War II, their states took on greater roles in the allocation of resources, as governments anxious to avoid the social conflicts of the inter-war years adopted activist economic policies and generous social benefits to construct a Keynesian welfare state (Offe 1983; Eichengreen 2007). However, economic recession and slower rates of growth during the 1970s gave rise to widespread disillusionment with existing modes of policy-making. In reaction, policy-makers began to argue that employment was the responsibility of markets rather than governments and growth could be restored only by expanding the ambit and competitiveness of markets (Hall 1993; McNamara 1998: Blyth 2002).

The pioneering steps were taken by governments elected under Margaret Thatcher in 1979 and Ronald Reagan in 1980. In the context of widespread fears about national decline, they promised to restore the prosperity of the nation by enhancing the role of markets vis-à-vis the state in the economy (Krieger 1986). Paradoxically, the initial requirement was a more assertive state (Gamble 1988). The two administrations initiated legislation to reduce the power of trade unions and fought high profile battles with British miners and American air controllers. In the name of deregulation, they privatized national enterprises contracted out public services, tightened social benefits, and made many markets more competitive (King 1987; Vogel 1998; Prasad 2006).

On the European continent and in Asia, the move to the market came more slowly. The Wende that Helmut Kohl promised Germany in 1984 proved more rhetorical than real, and a socialist government under François Mitterrand tried to revive French 
dirigisme before beginning a string of market-oriented reforms in 1983 (Hall 1986; Wood 2001). Other governments were often slower to act. With the adoption of the Single European Act of 1986, the European Community committed itself to more intense market competition and turned its Commission into an agent for market liberalization. By the early 1990s, markets were being liberalized in all the OECD countries, and liberalization continued until the global financial crisis of 2008.

In short, the past thirty years have been a neo-liberal era marked by the opening of international markets, the intensification of market competition, and the growing influence of markets over the allocation of resources. In labor markets, liberalization has featured initiatives to reduce employment protection, to make part-time and temporary employment more feasible, to tighten eligibility and replacement rates for unemployment or sickness benefits, and to weaken trade unions. In markets for corporate governance, neo-liberal initiatives reduced impediments to foreign direct investment, made corporate takeovers more feasible, and increased the power of shareholders relative to stakeholders. In markets for goods and services, analogous initiatives reduced barriers to trade, privatized public enterprises, encouraged the contracting out of public services, and opened markets to new competitors. Although these initiatives were more intense in some countries than others, as Peter Evans and William Sewell note in their chapter for this volume, Figure One indicates that the OECD countries moved broadly in these directions (cf. Hall and Thelen 2009).

The object of this chapter is to examine the effects of this turn toward more intense market competition on ordinary people in the developed democracies. We are especially interested in the distribution of well-being and the sources of social resilience 
sustaining it in the neo-liberal era. How have people fared in the context of this neoliberal era? Are they generally better or worse off? Which groups have benefited and which have lost in the face of these developments?

The answers to these questions are not obvious. On the one hand, there is a sound rationale in economic theory for expecting intensified market competition to improve economic performance and aggregate well-being by stimulating trade, encouraging innovation, and reducing consumer prices. On the other hand, intensified competition is likely to have restrained wages and made some jobs less secure, while the tightening of social benefits disadvantages those in precarious labor-market positions. Whether liberalization improved the overall well-being of all groups in society resists ex ante specification.

Even if we construe well-being in entirely material terms, measurable by income or wealth, the outcome remains unclear. On average, the OECD countries saw modest increases in national income and in income inequality during the 1980s and 1990s (OECD 2008). However, there is wide cross-national variation in the extent to which income inequality has increased as well as in the income ranges and types of income affected. In some countries, the distribution of earned income is not much more unequal today than it was at the beginning of the 1980s. In others, increases in earnings inequality have been offset by redistributive taxes and transfers. In general, inequality across households has increased less than across individuals. Thus, it is difficult to assess well-being on the basis of aggregate figures for income inequality (Gottschalk and Smeeding 1997; Pontusson 2005; Kenworthy and Pontusson 2005; Pontusson and Rueda 2009). 
Moreover, income is not synonymous with well-being, and market liberalization has effects that extend well beyond income. When markets become more competitive, people who have to sell their labor or goods face greater uncertainty and economic insecurity can depress well-being. Many jobs have become less secure, and many of the policy initiatives associated with liberalization, such as shifts away from pension plans offering defined benefits, reductions in unemployment benefits, and new limits on health benefits have forced many people to bear more of the risks associated with adverse life events and economic fluctuations (Taylor-Gooby 2004; Hacker 2004; Hacker et al. 2010).

The neo-liberal era has also seen the extension of market logics into ever more spheres of the life world (Habermas 1985; Sennett 2006). An increasing number of organizations, ranging from firms to universities and public agencies, are now subject to more competitive pressure. Although reforms of this sort can breathe new life into old organizations, they can also put those working in them under more strain (Hochschild 2003). They often alter the normative orders embedded in organizational culture, subordinating human relationships to competitive concerns (Sauder and Espeland 2009; Streeck 2009). Even family relations have changed, as more children are subjected to competitive pressures at ever earlier ages (Hochschild 2003; Levey 2010).

In short, the market liberalization of the 1980s and 1990s has had wide-ranging effects on multiple spheres of life. By opening up new opportunities, foreclosing others, and subjecting people to new pressures, it is likely to have been consequential for wellbeing in many ways. Where can these effects be observed? 


\section{Shifts in Worldview during the Neo-Liberal Era}

We begin by considering whether the neo-liberal era has had a pervasive impact on the worldviews of ordinary people. Above all else, this era was marked by a shift in reigning ideas about the value of market competition. Underpinning them were changes in the doctrines of mainstream economics. Under the influence of rational expectations theory, economists acquired a new skepticism about the value of macroeconomic management and discovered a 'natural' rate of unemployment reducible only through structural reform on the supply-side of the economy (Crystal 1979; Cuthbertson 2000). Informed opinion changed in tandem with these doctrines toward the view that markets are efficient allocators of resources and government intervention likely to impede that efficiency. The implications were that people should be paid by their performance and governments should not restrict competition or equalize incomes, lest they damage the capacity of markets to produce well-being for all. By 1985, the nostrums of the new economics were working their way into politics (Blyth 2002; Prasad 2006).

One notable feature of this movement was the breadth of its influence. Although parties on the political right led the way, they were soon followed by those on the mainstream left. Figure Two shows the movement, in seventeen developed democracies from 1945 to 2005, on an index reflecting party positions on eight economic issues central to neo-liberalism, such as the appropriate role of state and market in economic regulation and the priority to be accorded economic efficiency relative to social protection (Iversen 2006; Cusack and Engelhardt 2002). The solid line in the middle indicates the average position on this index of the parties in these legislatures weighted 
by their share of seats. ${ }^{1}$ Between 1980 and 1998, legislatures became significantly more neo-liberal, as parties on both the right and left moved in that direction.

Were these shifts in worldview simply an elite phenomenon or did they reflect changes in the beliefs of ordinary people as well? We are especially interested in three issues. Did neo-liberal ideas induce changes in people's thinking about how the economy should work, how they should behave, and how economic rewards should be distributed? The latter touches on what Europeans call 'social solidarity', namely, the willingness of people to see resources redistributed to those who are less well off (cf. Lane 1972; Hochschild 1981; Goldstein and Keohane 1993; Boltanski and Chiapello 1999). Unfortunately, long runs of relevant data are scarce, but some suggestive answers are available from the World Values Survey, which has asked a consistent series of questions of nationally-representative samples at five year intervals since 1981. Although not every country was surveyed in every wave, our observations cover eighteen OECD countries for a total sample of up to 47,890 respondents.

There is evidence that market-oriented ideas made important inroads into popular beliefs especially during the 1980s. With regard to how the economy should operate, the inclination of people in all income groups to regard 'competition' as good rather than harmful increased during the early 1990s, and, although support for competition declined in the second half of the 1990s, the balance of opinion remains favorable to it (see Figure Three). ${ }^{2}$ With respect to the distribution of economic rewards, consider views about what people who perform the same job with different degrees of competence should be paid. Market ideology usually specifies that people who perform better should be paid more, a view popular among those with higher incomes. As Figure Four indicates, support for 
this position increased significantly among people at all levels of income during the 1980s, and it has remained high ever since.

Since market ideology also endorses self-interested behavior, it is notable that the proportion of people who think it can be justifiable to avoid paying a fare on public transport increased from 33 percent in 1981 to 43 percent in 2005, a thirty percent rise. ${ }^{3}$ In broad terms at least, the market-oriented ideas popularized over the past thirty years do seem to have shifted the views of ordinary people about how the economy should function and what behavior is appropriate to it.

However, market ideas do not appear to have altered fundamental attitudes to social solidarity. Figure Five indicates that people in virtually all income groups across a wide range of countries became more supportive of the views that governments should take responsibility for providing for everyone and that incomes should be made more equal in the wake of the neo-liberal initiatives of the 1990s. ${ }^{4}$ Responses in successive surveys about the role of government reflect similar trends. On a battery of questions about whether it is the government's responsibility to redistribute wealth, provide jobs for everyone and benefits for the unemployed and elderly, the majorities supporting such measures in OECD countries shift very little between 1985 and 2006; and the proportion thinking the government has a responsibility to reduce income differences between the rich and the poor increases slightly from 68 percent in 1985 to 74 percent in 2006 (ISSP 2009). Although market-oriented ideas have left their mark on the popular imagination, they do not seem to have eroded feelings of social solidarity or the belief of a majority of citizens in a most OECD countries that governments bear responsibility for securing it. 


\section{Shifts in Well-Being during the Neo-Liberal Era}

Our primary concern is with well-being. We use the term 'well-being' to denote a person's welfare understood in broad terms, as a multidimensional phenomenon encompassing material circumstances, health and security. In keeping with a substantial literature, we measure it by the level of satisfaction people express with their lives (Helliwell and Barrington-Leigh 2010; Helliwell et al. 2010). ${ }^{5}$ This instrument allows people to define well-being in their own terms and, for assessing the impact of a multidimensional phenomenon such as market liberalization, it has advantages over narrower indicators that reduce a person's welfare to income (Sen 1999; Stiglitz et al. 2009; Nussbaum 2001). In addition, this approach allows us to evaluate the impact of changes in income on well-being. There is strong evidence that life satisfaction is a good indicator for quality of life, reflecting common conditions across national contexts and, in our dataset, it is highly-correlated with measures for other factors associated with the quality of life, such as health and the household financial situation (for reviews, see Veenhoven 1996; Diener et al. 1999; Helliwell 2008).

How did the experience of neo-liberal reform affect the well-being of ordinary people? Figure Six shows average well-being across eighteen developed democracies for three groups whom we will describe as the lower-middle class (at or below the $30^{\text {th }}$

percentile in the income distribution), the upper-middle class (at or above the $70^{\text {th }}$ percentile) and the middle class (between the other two groups). In keeping with the view that neo-liberal reforms promote prosperity, average well-being increased by a total of 3 percent between 1981 and 2005. However, that increase is modest compared with 
the 1.9 percent increase per year in gross domestic product (GDP) per capita for the OECD countries over this period. ${ }^{6}$

More important, the distribution of well-being became significantly more unequal over the course of the neo-liberal era. It is not surprising that the well-being of all three income groups improved during the 1980s, since 1981, our base year, came amidst the worst global recession since 1945. During the 1990s, however, only the upper-middle classes experienced increases in well-being, and the average well-being of the middle and lower-middle classes fell during the 1990s and early 2000s. In short, this was an era of winners and losers. Over these twenty-five years, average well-being increased by 2 percent for the upper-middle class but declined by 3 percent for the lower-middle class.

While these numbers may seem small, the gap is statistically significant $(\mathrm{p}=$ 0.0396) and striking given how stable national assessments of subjective well-being tend to be. As Easterlin $(1974,1995)$ and others have shown, those assessments do not move much even over decades of economic change; and, at the individual level, changes in subjective well-being induced, for instance, by changes in income tend to have a short half-life (Di Tella et al. 2010; Suh et al. 1996). The gap in average well-being between the upper-middle and lower-middle classes in 2005 is more than twice the standard deviation in the country averages for well-being over this period.

To what extent is this increase in inequality attributable to liberalization processes that made markets more open and competitive as opposed to other developments over this period? Given limitations in the available data, this is an issue we cannot resolve definitively. Some analysts have argued that increases in income inequality were inspired by technological change, which privileged those with technical skills relative to 
the low-skilled. However, the evidence suggests that technological change accounts at best for a small portion of the rise in income inequality in the OECD over this period (Harjes 2007; cf. Autor et al. 2005). Others attribute such distributive effects to the increasing flows of trade and capital associated with globalization. By making low-skill production in the developing world more feasible, the opening of global markets intensified competition and increased relative returns to skill in the developed world (Wood 1994; Leamer 1996; Antras et al. 2006). However, governments had to decide to make international markets more open, and we see the opening of global markets as one aspect of broader liberalization processes with political origins.

Many domestic policies associated with liberalization also had direct consequences for the lower middle class. Efforts to weaken trade unions were largely successful. The proportion of the OECD workforce that is unionized dropped from 33 percent in 1980 to 18 percent in 2008, and the strength of the trade union movement is closely correlated with wage levels at the lower end of the income spectrum (Card and Di Nardo 2002). Steps to reduce employment protection and encourage temporary employment contracts reduced the job security of large segments of the workforce, as increasing turnover rates indicate. At a basic level, there is a natural class bias to liberal reforms. Reforms that extend the purview of markets often enhance the aggregate 'efficiency' of allocation, but they also privilege those with access to marketable resources, such as capital and high levels of skills typical in the upper middle class, relative to those without them. Intensifying market competition magnifies the distributive effects that follow from disparities in marketable resources. 
By contrast, it is unlikely that increasing inequality in well-being stems from the two other socioeconomic developments most prominent in this era, namely, the entry of women into the paid labor force or the rise of service sector employment. Although entry into the labor force seems to have depressed the life satisfaction of women, women from the upper and lower middle classes enter the labor force in roughly similar proportions, and we did not find a significant gender-based class difference in our data (Blanchflower and Oswald 2004; Stevenson and Wolfers 2009). Although there is significant crossnational variation in the types of service sector jobs created, the expansion of service sector employment was also a cross-class phenomenon (Esping-Andersen 1999).

In sum, one of the most striking features of the neo-liberal era has been a shift in the distribution of well-being. After narrowing slightly in the 1980s across the OECD, inequality in well-being increased markedly after 1990, as well-being rose among the upper middle classes and stagnated among other groups.

\section{Cross-National Variation in Well-Being}

Although the distribution of well-being became more unequal in most countries in our sample over the neo-liberal era, that increase was much larger in some societies than others. How is this cross-national variation to be explained?

For the purposes of cross-national comparison, we construct an index of inequality in well-being that indicates, for each country at each point in time, the ratio of the average level of life satisfaction reported by people in the upper-middle class (namely, in the top three income deciles) to the average level of life satisfaction reported by people in the lower-middle class (in the bottom three income deciles). We compare 
well-being across these large groups rather than small bands at the top and bottom of the income distribution in order to capture the life situations of a majority of people and to minimize the measurement error that might arise from looking at smaller groups. In intuitive terms, a score of 110 on this index means that, for country $\mathrm{x}$ at time t, the average well-being of people in the upper-middle classes was 10 percent higher than the level of well-being among people in the lower-middle classes. To correct for the possibility that people may be culturally less inclined to express satisfaction with their life in some countries than others, this measure compares the responses of co-nationals. Thus, it provides a measure of inequality in well-being that is broadly comparable across countries and time.

Figure Seven shows the level of inequality in well-being in each of the OECD countries in our sample in 2005, and Figure Eight the average annual rate of change in this index between 1980 and 2000. Significant differences are visible. After two decades of the neo-liberal era, the distribution of well-being is more equal in Ireland, Australia, Italy and the Netherlands, but relatively unequal in Germany, Denmark, the US and Finland. To appreciate the substantive significance of these inequalities, note that, in our sample, the ratio of well-being of a full-time worker compared to that of an unemployed worker, whose well-being is typically depressed by unemployment, is 1.17 , not so different from the ratio across income groups in countries where well-being is distributed most unequally (cf. Blanchflower and Oswald 2004: 1373).

Figure Nine reports each change in well-being in each country in our sample over all sub-periods between 1981 and 2005, arrayed from left to right based on the extent to which the change marked an increase in inequality in well-being, decomposed into 
changes in well-being among the upper and lower-middle classes. The circles show the change in well-being over the sub-period among the lower-middle class and the diamonds the change among the upper-middle classes. It is apparent that, where large declines in well-being took place (to the right in the diagram), they were attributable mainly to a decline in well-being among the lower-middle class.

Thus, the problem becomes primarily one of explaining why the relative wellbeing of the lower-middle class is lower in some times and places than in others. This is likely driven in fundamental ways by the economic situation of the lower middle classes. Three types of material factors might matter. The first is the level of national income: where it is higher, everyone should be better off and this might improve the well-being of some groups more than others, although we have no ex ante expectation about which groups will benefit most. A second relevant factor is the distribution of income: where it is more equal, well-being should be more equally distributed. The third factor is the rate of unemployment. Because the incidence of unemployment is typically higher among those at lower incomes, where the level of unemployment is lower, the lower-middle class may be relatively better off.

To assess these propositions, we estimate the impact of GDP per capita, the standardized rate of unemployment, and the Gini coefficient for the inequality of market income prior to taxes and transfers on the index for inequality in well-being, using an ordinary least squares regression covering all countries and periods in our sample. Since we have few observations for each country, it is not practicable to include country-level fixed effects, but we do control for types of welfare state (Esping-Andersen 1990). The results are in models 1 and 2 of Table One. ${ }^{7}$ They suggest that, where market income 
inequality is higher, inequality in well-being will also be greater. Higher levels of national income may also increase inequality in well-being, suggesting that, at least in this period, higher levels of prosperity were shared unequally. Both coefficients are just significant at the .05 level. Surprisingly, we find no systematic relationship between the rate of unemployment and inequality in well-being. ${ }^{8}$ These results have to be treated with caution because they are not robust to the inclusion of a time-trend, but they suggest that income inequality contributes to inequality in well-being, without fully determining it, as the low $\mathrm{R}^{2}$ indicates.

The country rankings in Figure Seven are intriguing. While we might expect inequality in well-being to be relatively high in countries such as the U.S. and U.K. where inequalities in income and health are significant, it is also high in countries such as Germany, Denmark and Finland where corresponding inequalities in income and health have long been lower and egalitarian political traditions stronger. To some extent, these figures reflect the fact that liberalizing reforms have had an important impact on relative well-being even in these countries, but they probably also reflect the way in which existing political traditions mediate the experience of such reforms. Assessments of wellbeing are conditioned, not only by circumstances, but also by expectations; and, in countries where welfare states have been relatively generous and egalitarian economic outcomes more prized, neo-liberal reforms and accompanying increases in income inequality may well have depressed the sense of well-being of the lower-middle class more than in countries where people were accustomed to higher levels of inequality.

This interpretation is consistent with the findings of Alesina et al. (2004) that income inequality reduces the subjective well-being of those in the bottom half of the 
income distribution more in Europe than in the United States, and it conforms to the fact that the coefficients on type of welfare state (in Table One) indicate that, at any given level of income inequality, members of the lower-middle class in countries with continental or social democratic welfare states are likely to feel less well-off relative to members of the upper middle class than their counterparts in the liberal market economies (Esping-Andersen 1990; Hall and Soskice 2001). Similar considerations may explain why inequality in well-being did not increase in Ireland and Spain (see Figure Eight). Both countries experienced economic transformations over this period whose fruits likely exceeded the expectations of many in the lower-middle class (McGraw forthcoming).

\section{Sources of Social Resilience}

Many people faced challenges to their well-being during the 1980s and 1990s. Stylizing slightly, the intensification of market competition can be seen as an economic shock. The resulting dislocation put the well-being of the lower middle class at particular risk. However, the consequent levels of well-being are, not simply a function of the magnitude of the shock, but conditioned by the social resilience of those at risk. The core issue is: how is such resilience constituted? What are the sources of social resilience on which people facing more economic insecurity, potential unemployment and declining incomes might draw to preserve their well-being in the face of such developments? For approaches to this, we draw on two kinds of theoretical literatures.

Consider first the individual-level strategies that people can adopt. Multiple literatures suggest that, in challenging situations, individuals turn to other people for 
support, whether informational, emotional or logistical, often to compensate for the material resources they lack. Studies of life under communism find that, when resources are scarce, people seek assistance from their relatives, friends, and colleagues - for help in securing goods, small services, and to navigate the bureaucracy (Wedel 1986; Hann 1993). Studies in population health find that people who become ill recover more quickly if they can rely on close friends or relatives, and people tied into social networks enjoy better general health than those who are not (Berkman and Glass 2000, Berkman et al. 2000). Building on Link and Phelan (1995), the contributors to Successful Societies (Hall and Lamont 2009) describe social connectedness as a 'social resource' on which people draw to enhance their capabilities for coping with life challenges. The inference is that social connectedness may be a buffer against increases in the 'wear and tear' that people experience when markets become more competitive.

In order to assess this possibility, we estimate the effect of social connections on well-being at the individual level for everyone in our sample between 1980 and 2005, using hierarchical linear models with cross-level interactions. Several kinds of social connectedness might matter, ranging from intimate ties to family members, social connections to friends, and the relationships that come with membership in voluntary associations. Therefore, we measure social connectedness on three dimensions, based on what respondents said about how important ties to family and friends were to them and the number of associations to which they belonged. The estimations contain a range of controls for the other factors that might matter to well-being, including income (measured by household income decile), type of occupation, employment status, years of education, 
age and gender. We include time and country fixed effects and look where appropriate for non-linear effects.

Table Two reports the results. The material determinants of well-being all have the expected effects. Well-being increases with income but it is lower among unskilled and semi-skilled manual workers relative to managers and professionals (not shown) and among the unemployed. With respect to age, well-being has a U-shaped relationship, lower among the middle aged than the young but rising again later in life. However, Model 2 shows that all three types of social connectedness also have a statisticallysignificant relationship to a person's well-being in this period. Ties to family are most closely associated with well-being, followed by ties to friends, while membership in associations had a smaller but significant effect. Strong ties to friends improve wellbeing as much as a movement up two income deciles would, and strong ties to family have an effect on well-being equivalent to a movement up five income deciles. The conclusion we draw is that social connectedness has been an important source of social resilience during the neo-liberal era. ${ }^{9}$

However, there is a distributive dimension to these results: social connectedness matters more for the well-being of the lower-middle class than of the affluent. In model 3 of Table Two, we include a term that interacts income with membership in associations. The negative coefficient indicates that membership in associations improves well-being for people with low incomes more than for those with higher incomes. ${ }^{10}$ By the same token, the poor suffer greater losses in well-being from lower levels of social connectedness than do the affluent. Moreover, social connectedness can be seen as a feature of social structure and, just as the economic structure of capitalist societies 
distributes material resources unequally, the social structure of those societies tends to distribute social resources unevenly. Social connectedness is stratified by social class. As Table Three indicates, in virtually all OECD countries, people in higher social classes have denser networks of social connections than those in lower social classes. In sum, social connectedness is especially important to the well-being of people in the lowermiddle class but less available to them than to people in the upper-middle class.

As Putnam (2001) and others have observed, of course, people may benefit from the density of social networks in a community in ways that are independent of their own social connections (Schneepers et al. 2002; Sampson et al. 2002); and we find some confirmation for this in our multi-level estimations. The average level of associational memberships in a country has a statistically-significant impact on people's well-being independent of their own membership in such associations (model 3 in Table Two).

Broadly speaking, these results suggest that some important sources of social resilience are rooted in the structure of social relations. In some respects, however, they may reinforce, rather than even out, inequalities in well-being. If social connectedness is especially important to the well-being of people in the lower middle class, it is also usually less available to them than to members of the upper middle class; and more intense market competition can disrupt these connections, as it does, for instance, when people are forced to move to find new employment. We do not find any general decline in social connectedness over this period, but such issues deserve further investigation, as do the effects that might follow from cross-national variation in social structure (cf. Scheepers et al. 2002; Barnes et al. 2010). We find that, in countries with denser networks of social connections, average well-being is higher, but, where social 
connectedness is distributed more unequally across income groups, the relative wellbeing of the lower-middle class may suffer.

However, people do not rely solely on individual-level strategies to cope with challenges to their well-being. Those challenges can also be addressed through collective action. We consider two modes of collective action especially relevant to the challenges posed by neo-liberalism, namely those that operate through the trade union movement and those that democratic governance makes possible.

The effect of trade unions on well-being is of special interest during the neoliberal era, because unions were important sources of resistance to neo-liberal measures that would make employment less secure, wage competition more intense and social benefits more restrictive. A large literature suggests that trade unions can improve the well-being of their members and, as political actors, they often agitate for measures aimed at improving the well-being of the lower middle-class more generally (Freeman and Medoff 1984; Hall and Soskice 2001; Radcliff 2005; Flavin et al. 2010).

Democratic governments were also potentially important vehicles for collective response to the challenges of the neo-liberal era. Some classic views portray democratic governments as instruments that harnesses advancing knowledge to a popular will in pursuit of a wider social welfare (Beer 1974; Held 2006; Hall 2010). In the neo-liberal era, of course, governments were part of the problem as well as the solution: statesponsored initiatives to deregulate markets were central to intensifying market competition. However, as Polanyi (1944) observes, the governance of markets is ultimately a double-sided affair. Governments create markets, but they also offer protection from the worst effects of market competition. A failure to do so endangers 
their chances for reelection, if not the stability of the social order (Pacek and Radcliff 2008; Flavin et al. 2011).

Of course, both of these contentions are controversial. Few doubt that trade unions improved the living standards of the workforce in previous eras, but there is debate about their benefits during the neo-liberal era (Rueda 2007). A sizeable literature sees the efforts of trade unions to raise wage floors, resist lay-offs, and limit the reorganization of production as impediments to the well-being delivered by flexible markets (Hirsch 2003; Oswald 2005). Some analysts see democratic governments in similar terms, as sectarian agents more likely to deliver rents to their partisans than to serve the well-being of the populace as a whole (Bates 1981; Tanzi 2005; Hacker and Pierson 2010). Therefore, these issues deserve empirical scrutiny.

To assess the contention that trade unions preserved well-being in the face of the challenges of the neo-liberal era, we estimate a hierarchical linear model with intercepts that vary by country-wave and a wide range of controls for the determinants of wellbeing at the individual level. The results reported in model 4 of Table Two indicate that trade union density at the national level, i.e. the proportion of the national workforce belonging to unions, is positively associated with the well-being of individuals in these countries over this period and statistically-significant at almost the .01 level. ${ }^{11}$ Moreover, this effect is present even when we control for union membership at the individual level. In short, trade unions sustain the well-being of large portions of the populace, not simply of their own members (see also Flavn et al. 2010). They operate as factors of social resilience by virtue of how they defend social solidarity in the national political economy. 
Can democratic governments have similar effects? To examine this possibility, we estimate the impact of social spending (as a share of GDP) and of the redistributive efforts of governments on the index of inequality in well-being for each of our country periods. Our expectation is that social spending will have little effect on inequality in well-being. Although it increased on average in the OECD from 16 percent of GDP in 1980 to 21 percent in 2005, social spending is a blunt instrument for addressing inequalities in well-being because many of its beneficiaries are relatively affluent recipients of retirement and other benefits. By contrast, the government's redistributive effort is much more likely to reduce inequality in well-being because it entails the redistribution of income from upper to lower income earners through taxation and transfers. As an indicator for redistributive effort, we take the difference between the Gini coefficient for household market income (before taxes and transfers) and the Gini coefficient for disposable household income (after taxes and transfers) in each period.

The results are reported in Table One. As expected, aggregate social spending has no effect on inequality in well-being (model 3). However, model 4 indicates that a government's redistributive efforts reduce inequality in well-being by a substantial amount (statistically significant at the .03 level). We explore the issue further by incorporating a term for the government's redistributive effort into a multi-level model for determinants of individual well-being which controls for other factors. In Table Two (model 5), the relevant coefficient is positive and statistically-significant at the .05 level. Moving from the minimum to the maximum level of redistribution present in this sample increases average well-being by about as much as an increase of $\$ 30,000$ in average 
income would. This suggests that the efforts of governments to redistribute resources during the neo-liberal era improved the well-being of large segments of the population.

In other words, democratic governments can also be important sources of social resilience for the populace, by virtue of their capacities to redistribute income. However, it should be noted that there is wide variation in the extent to which governments made such efforts and controversy over what drives them. Some attribute the success of redistributive coalitions to a country's electoral rules, others to its longstanding cleavage structures and political traditions, or to the organizational power of the political left (Huber and Stephens 2001; Swank 2002; Iversen and Soskice 2006; Pontusson and Rueda 2009, see also the chapter by Bouchard). Thus, there are second-order issues to this dimension of social resilience that are beyond the scope of this chapter to explore.

\section{Conclusion}

The distribution of well-being has become markedly more unequal during the neo-liberal era. Although overall well-being in the developed democracies increased slightly during the 1980s, average well-being among the lower-middle class was only 88 percent of its level among the upper-middle class by 2005, down from 92 percent in the early 1980s; and in some countries it fell by as much as 17 percent.

From an egalitarian perspective, this development is cause for concern. After three decades in which democratic welfare states fulfilled their promise to improve wellbeing for all, they have presided over three decades in which well-being increased only for those in the most privileged strata of society. The fruits of post-industrial capitalism 
are being distributed less equally today than they were thirty years ago, and the wear and tear of daily life has increased for many people.

However, these developments are troubling from other perspectives as well. In particular, they may be contributing to fissures that threaten intractable social conflict. One of the achievements of the post-war Keynesian welfare state was to displace class conflict from the political arena into the industrial arena, where regularized collective bargaining in the context of steady economic growth ultimately muted it (Lipset 1964; Offe 1983). Despite some resurgence in the late 1960s and 1970s, class conflict of the sort that dominated interwar politics has never returned (Crouch and Pizzorno 1978; Dalton et al. 1984). Rising in its stead, however, is increasingly bitter conflict over immigration and ethnicity. Across the developed democracies, the principal challenge to established political parties comes, not from a radically-egalitarian left, but from a radically-nationalist right, incensed to see people of different origins, ethnicities and religions take up places in society (Kitschelt 1997). The many political reflections of this movement include the French National Front, the Austrian Freedom Party, the Swedish Democrats and the American Tea Party movement.

This conflict is normally associated with the effects of globalization and its continental counterpart, the European Union, which have promoted increases in immigration. However, levels of immigration alone do not explain much of the variation in support for anti-immigrant parties (Lubbers and Scheepers 2000; Van der Brug et al. 2005; Swank and Betz 2002). Other factors are at work here. We suspect that one of those factors is the growing discrepancy in well-being between social classes. Those who fan the flames of ethnic division typically draw on the diffuse discontents people feel 
about their lives, and, among the lower-middle class, twenty years of stagnating wellbeing has provided fuel for those flames.

There is some evidence for this proposition. Resentment of immigrants has increased in the developed democracies since 1980. While 8.5 percent of people in our sample said they would not like to have an immigrant as a neighbor in 1981, 12.2 percent said so in 2005, an increase of almost 50 percent. This trend is notably independent of broader changes in values over the period. Asked whether they would teach their children tolerance, in 2005, 83 percent of respondents said they would, compared with 52 percent in 1981. Even more telling are the estimations reported in Table Four in which we examine the impact of inequality in well-being at the national level on feelings of hostility to immigrants (measured by the percent of respondents who mention not wanting to have an immigrant or foreign worker as a neighbor) at five points in time between 1980 and 2005. Higher levels of inequality in well-being have a statistically significant effect (at about the .05 level) on hostility to immigrants. By contrast, generalized support for tolerance (measured by the percentage of people who say they would teach tolerance to their children) has no impact on attitudes to immigrants. Although many factors condition hostility to immigrants, including discourse in the public realm, where the gap in well-being between the lower- and upper-middle classes is larger, hostility to immigrants is likely be more prevalent (cf. Andersen and Fetner 2008). In sum, rising inequality in well-being does not simply increase relative deprivation. It also threatens the social solidarity of societies in ways that portend growing social conflict. Support for measures to make incomes more equal, which is one indicator for social solidarity, has increased from 41 percent in favor in 1990 to 50 
percent in 2005; but hostility to immigrants is another indicator of the limits to social solidarity, and it has remained high since 1990.

The concept of social resilience has also been central to our concerns. In the social sciences, there are two quite different literatures on resilience. One in psychology analyzes resilience as an attribute of individuals, usually acquired in childhood or adolescence as a result of experience with a caring family or role models in the local community. From this perspective, personal capacities for resilience allow a person to retain emotional health and achieve goals, such as good educational results, in the face of adversity, such as the loss of a parent or a decline in family income (Schoon 2006, Ungar 2008). A second literature in ecology sees resilience as an attribute of a physical or human system based on features that allow that system to return to a favorable equilibrium in the face of shocks engendered by climate change, plague or other environmental developments (Adger 2000; Folke 2006).

By contrast, we construe social resilience as an attribute of social groups, whether understood as communities, nations or social classes, which reflects the ability of the group to sustain its well-being in the face of challenges. This formulation has implications for where we look for the sources of social resilience. It directs our attention to experiences the group has in common and to the institutional or cultural frameworks that structure them. We see the factors structuring relationships within and between groups as key mediators of their response to change.

Several dimensions of these institutional and cultural frameworks have the potential to confer resilience on a social group. These include some we have not examined here, such as the collective narratives that are constitutive elements of a 
group’s identity, the shape of a society's status hierarchy, and various features of its collective organization that condition the potential for mobilization (Bouchard 2003; Lamont 2000; Cornell and Kalt 2000; Barnes et al. 2010; Putnam 2000). Because of the data available to us, we have put special emphasis on the dimensions of social structure associated with social connectedness. Social connectedness emerges here as a crucial social resource intimately linked to social resilience. Our findings suggest it has been especially important to the capacity of members of the lower-middle class to sustain their well-being during the neo-liberal era, and there would be real value in looking more closely at how it varies across countries and over time (Barnes et al. 2010).

We have also argued that trade unions and democratic governments can be significant factors of social resilience, namely, vehicles for collective response to socioeconomic challenges capable of sustaining the well-being of ordinary people. Our observations about trade unions are especially consequential in light of the dramatic losses in membership they have suffered during the neo-liberal era (Pinto and Beckfield 2011; Baccaro and Howell 2011). If our findings are correct, many societies are losing one of their most important sources of social resilience. In the same vein, this analysis carries implications for how we view democratic governance. As Beer (1974) observed some decades ago, in principle, democratic governments can be vehicles for the formulation and implementation of common purposes. In many instances, they are no more efficient at this than capitalist economies are at securing economic growth, but, from the standpoint of resilience, democratic governments provide a capacity for concerted response not present in other biological systems; and there is scope for 
exploring further the conditions under which they are indeed sources of social resilience (cf. Mayntz and Scharpf 1987).

Finally, our analysis points to the value of looking further into well-being, its distribution and determinants. Although many studies emphasize how the distribution of income changed during the neo-liberal era, its initiatives conditioned well-being in other important ways. Assessments of well-being raise inevitable measurement issues, but they hold the potential for developing a better understanding of the contribution that nonmaterial, as well as material, factors make to social welfare (Stiglitz et al. 2009). There are important research agendas here worth pursuing. 
FIGURE ONE: Movement in indicators of liberalization, 1980-2010

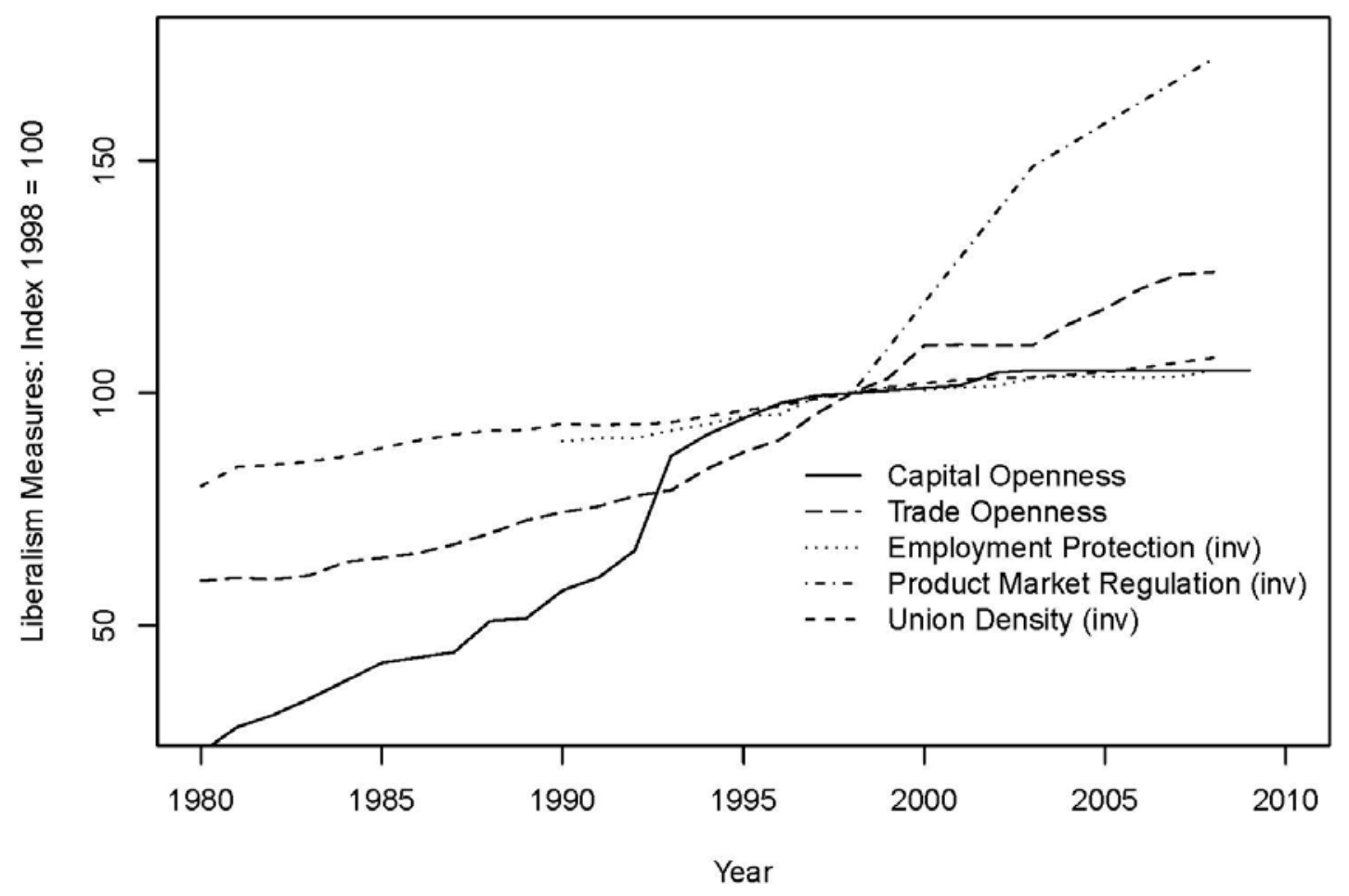

Notes: Indices are constructed from OECD measures for product market regulation, employment protection, percent of the labor force in trade unions, and exports and imports as a share of GDP. 
FIGURE TWO: Change in Party Positions on the Economic Ideology Index, 1945-2005

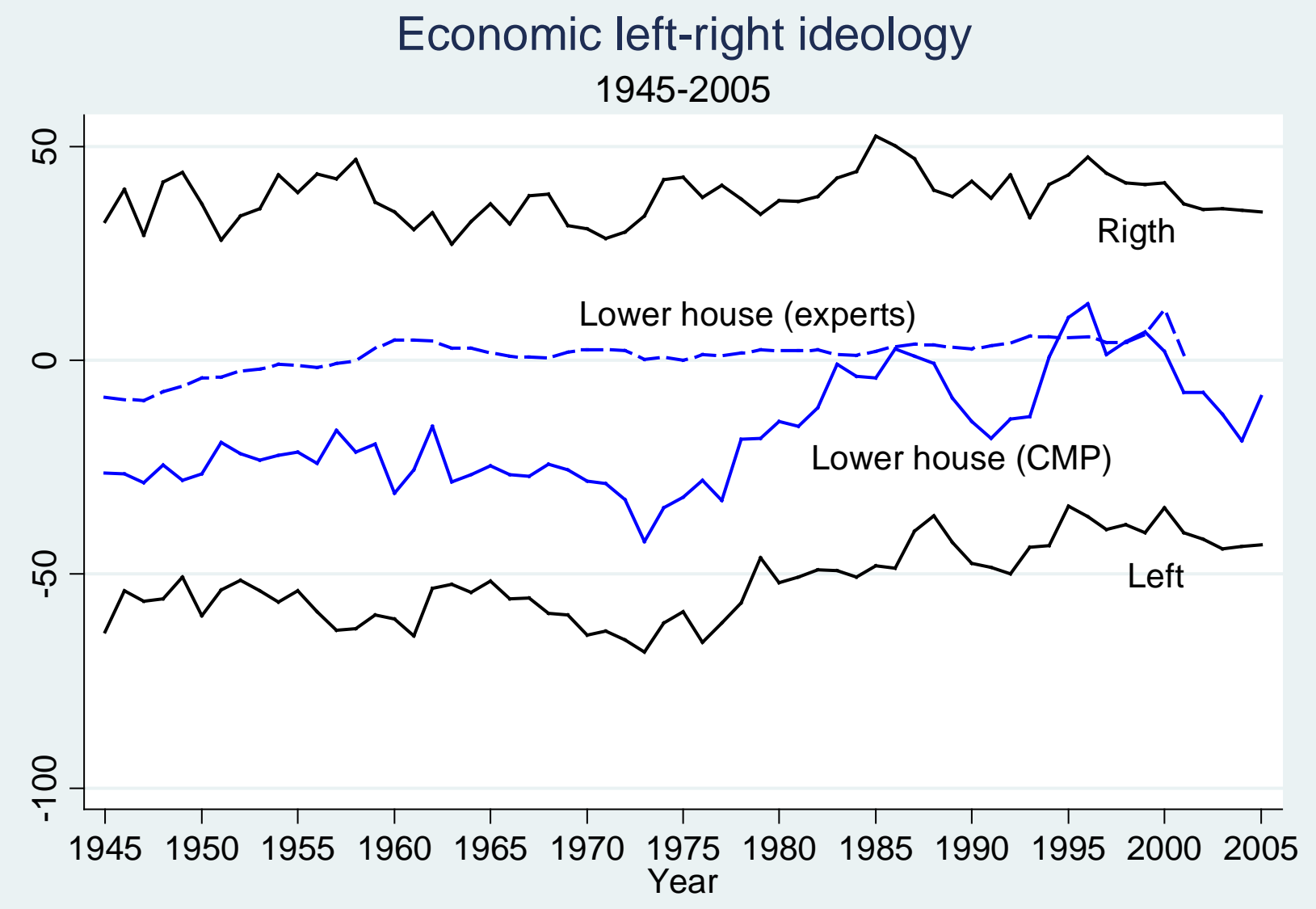

Notes: The solid middle line indicates the mean position of legislators on an economic ideology index where higher values reflect more market-oriented policy positions.. The top and bottom lines indicate the mean position of parties on the right and left of the political spectrum on this index. The dotted line indicates the balance of seats in the legislatures held by parties classified by experts as being on the left and right of the political spectrum.

Source: Data provided by Torben Iversen. See also Iversen 2006. 
FIGURE THREE: Views about whether competition is good or harmful across three income groups

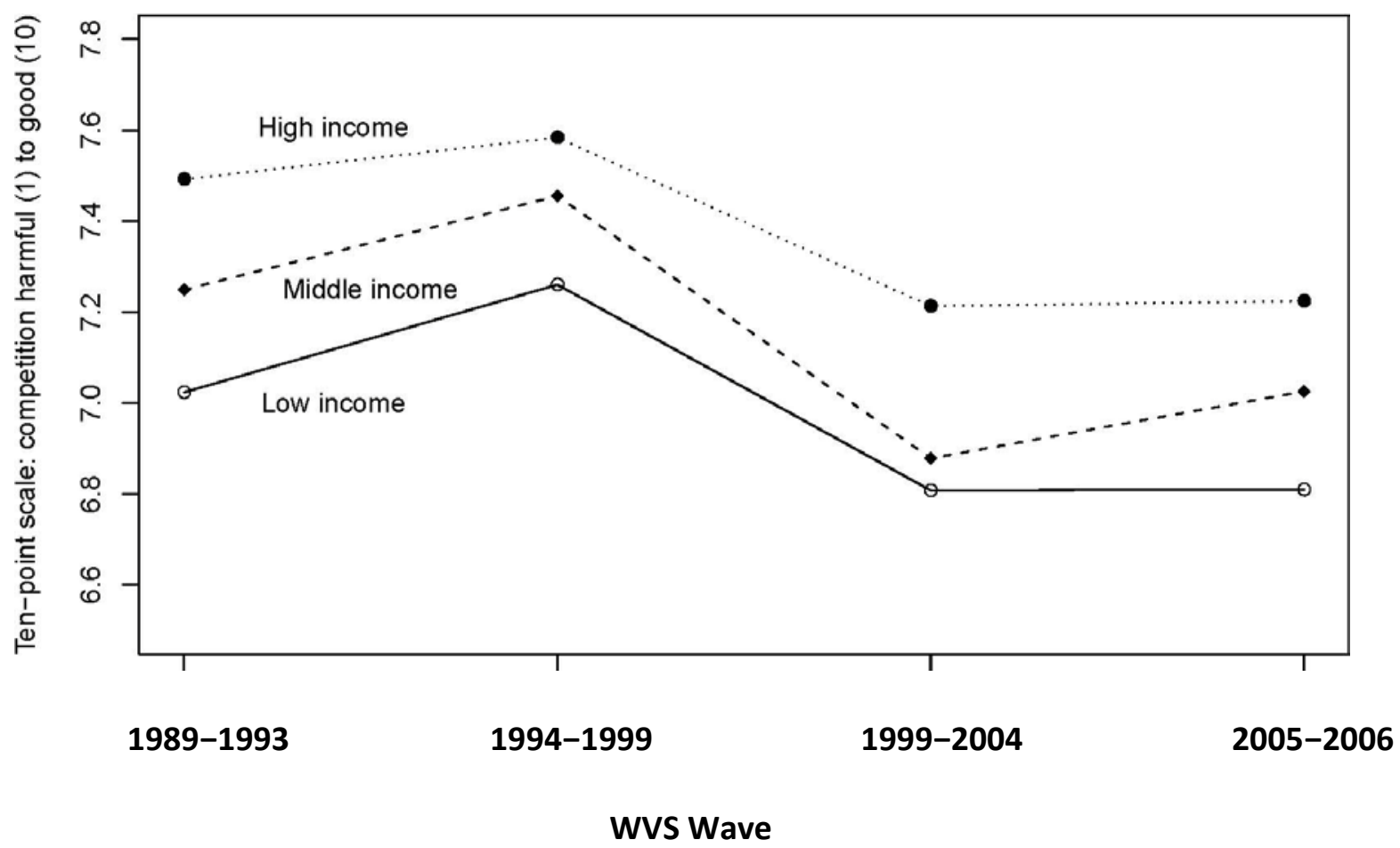

Note: Values on the $\mathrm{Y}$ axis indicate the mean score on a scale of 1 to 10 where 'harmful' Is 1 and 'good' is 10.

Source: World Values Survey. 
FIGURE FOUR: Percent of people who think it fair to pay the ablest more (by income group)

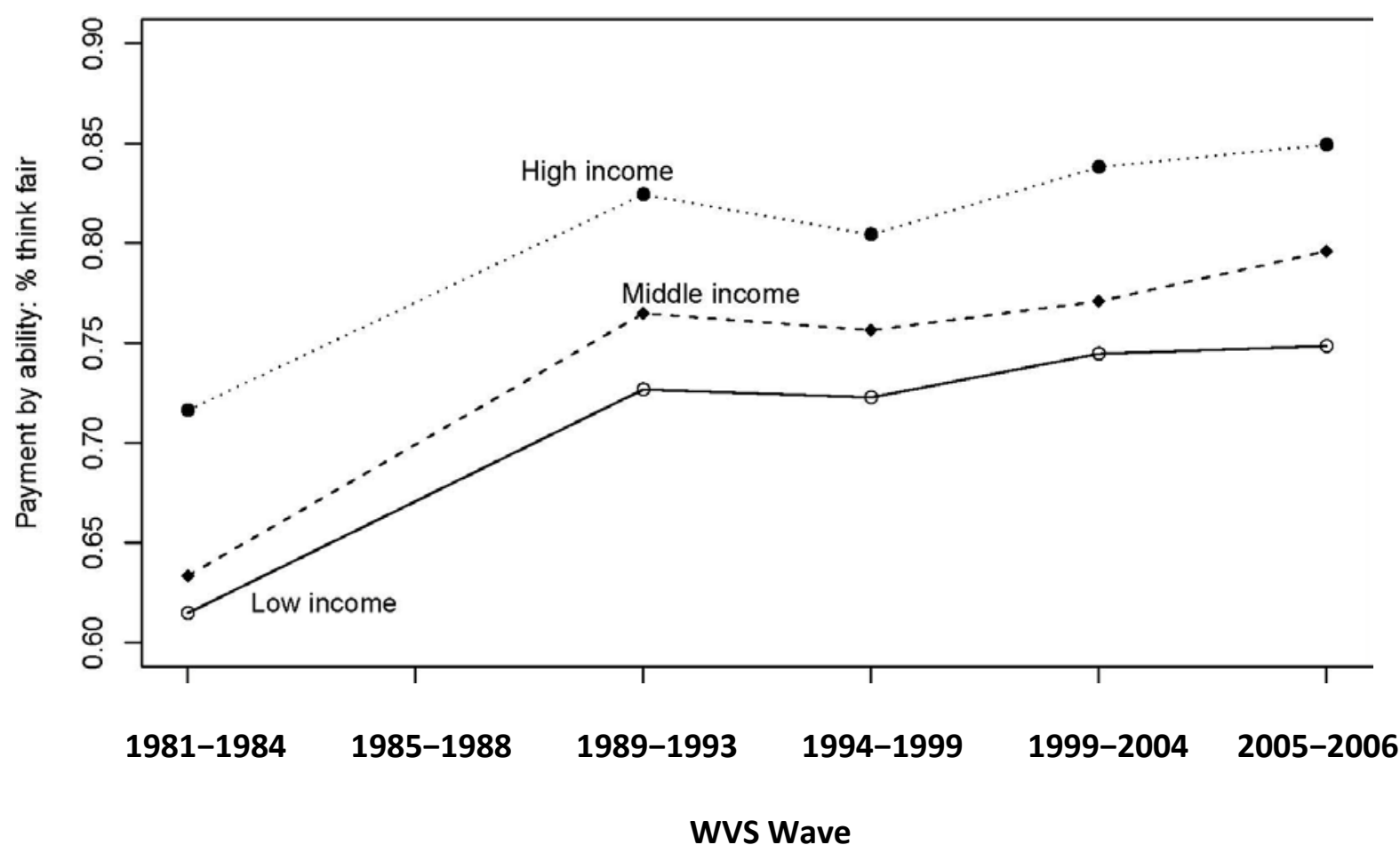

Note: Figures on the $\mathrm{Y}$ axis are percent who think it is fair to give more to pay to those who perform better rather than offer the same pay for the same job.

Source: World Values Survey 
FIGURE FIVE: Views about the responsibilities of the state and income equality by income decile

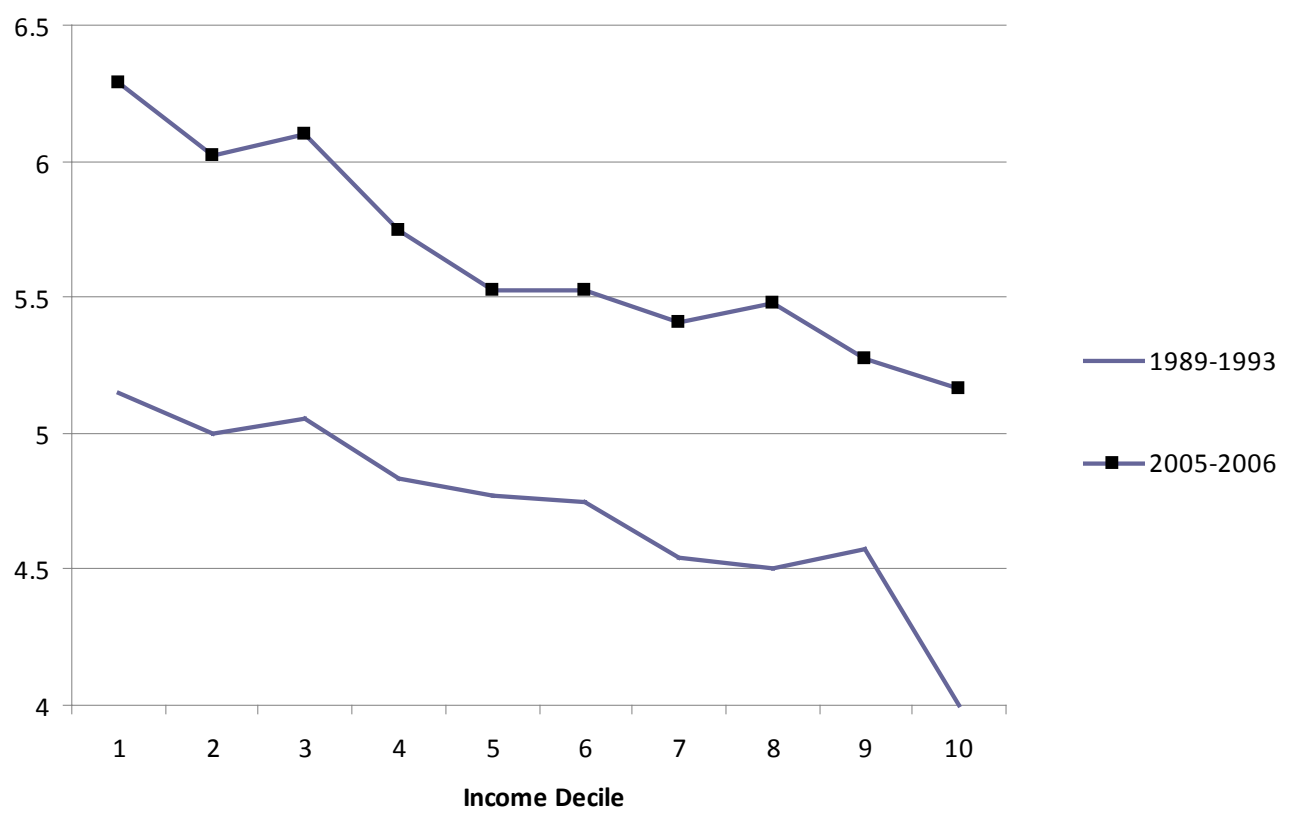

The state should take more responsibility for ensuring everyone is provided for (10) v. individuals should take more responsibility for providing for themselves (1) - average on a scale of 1 to 10

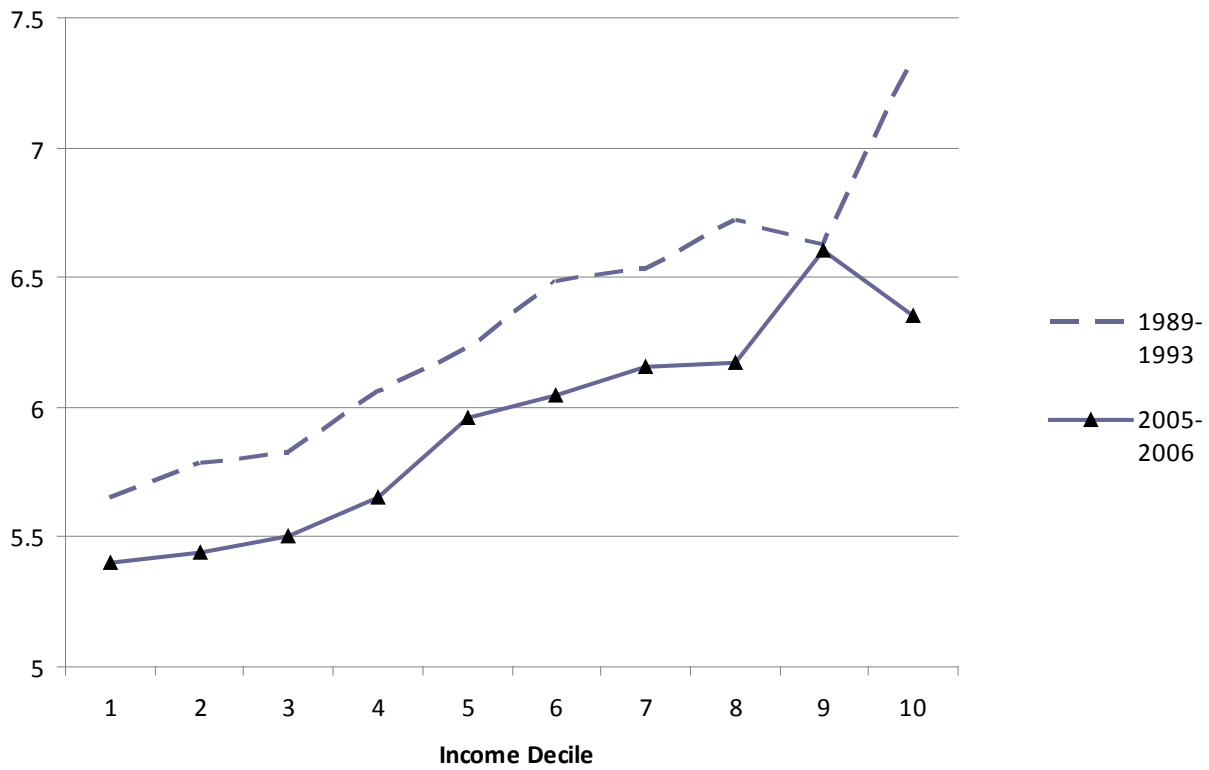

Incomes should be more equal (1) v. there should be greater incentives for individual effort (10) - average on a scale of 1 to 10 
FIGURE SIX: Level of well-being over time in three income groups

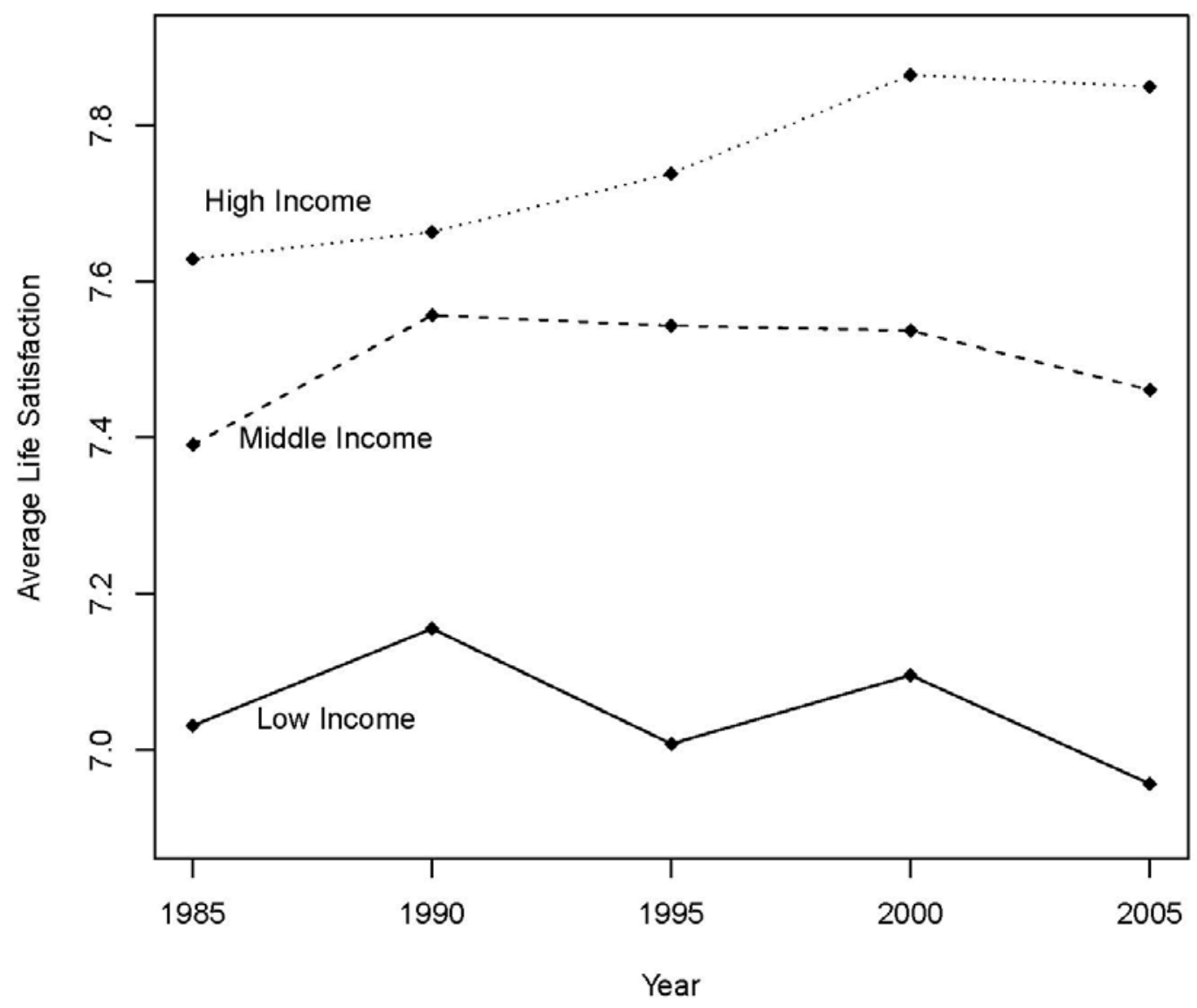

Source: Authors' calculations, World Values Survey 
FIGURE SEVEN: Inequality in well-being between the upper-middle class and lower-middle class in 2005

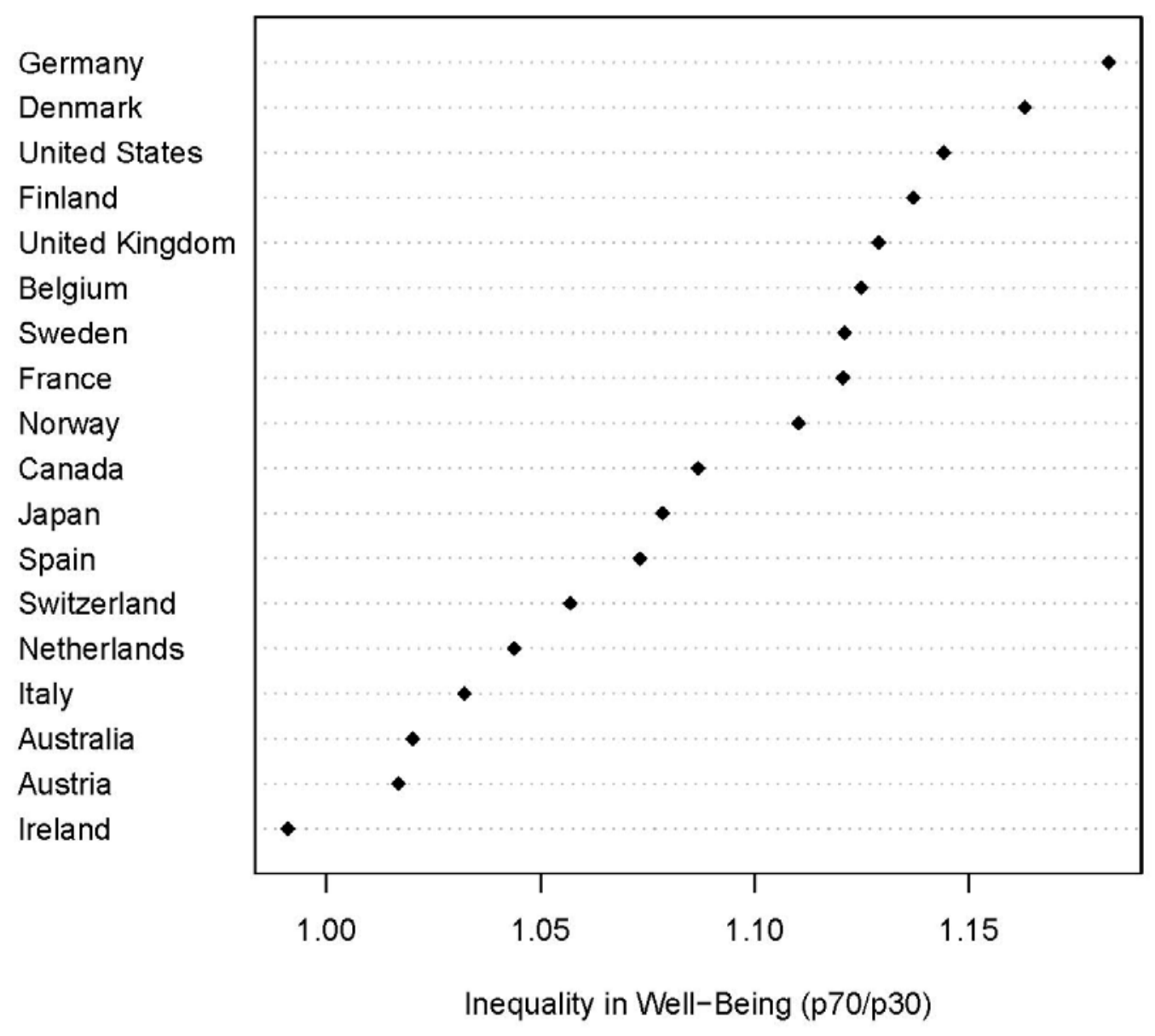


FIGURE EIGHT: Average annual change in inequality in well-being, 1985-2005

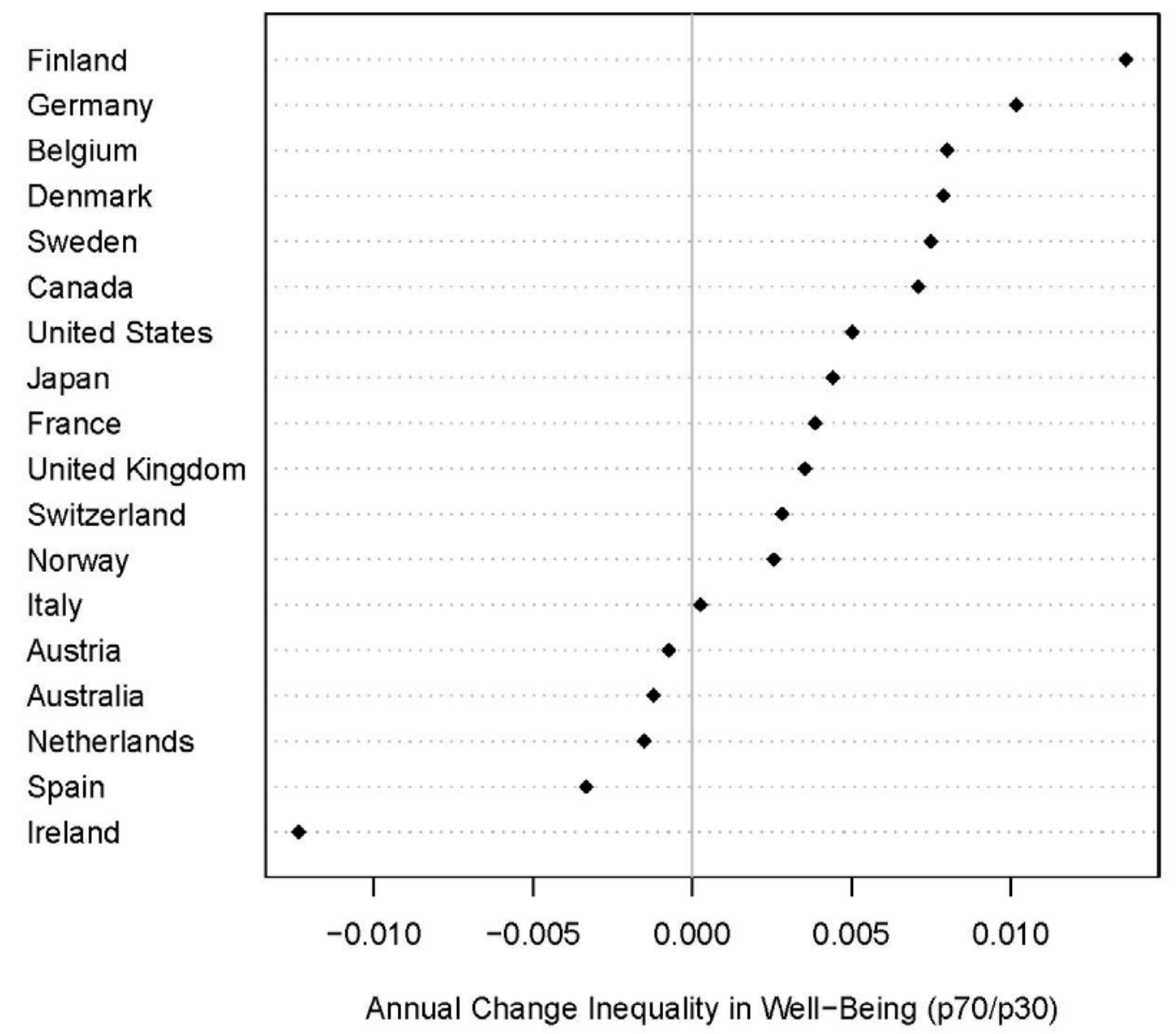


FIGURE NINE: Changes in well-being of the lower-middle and upper-middle classes across each period from 1980-2005 in the OECD

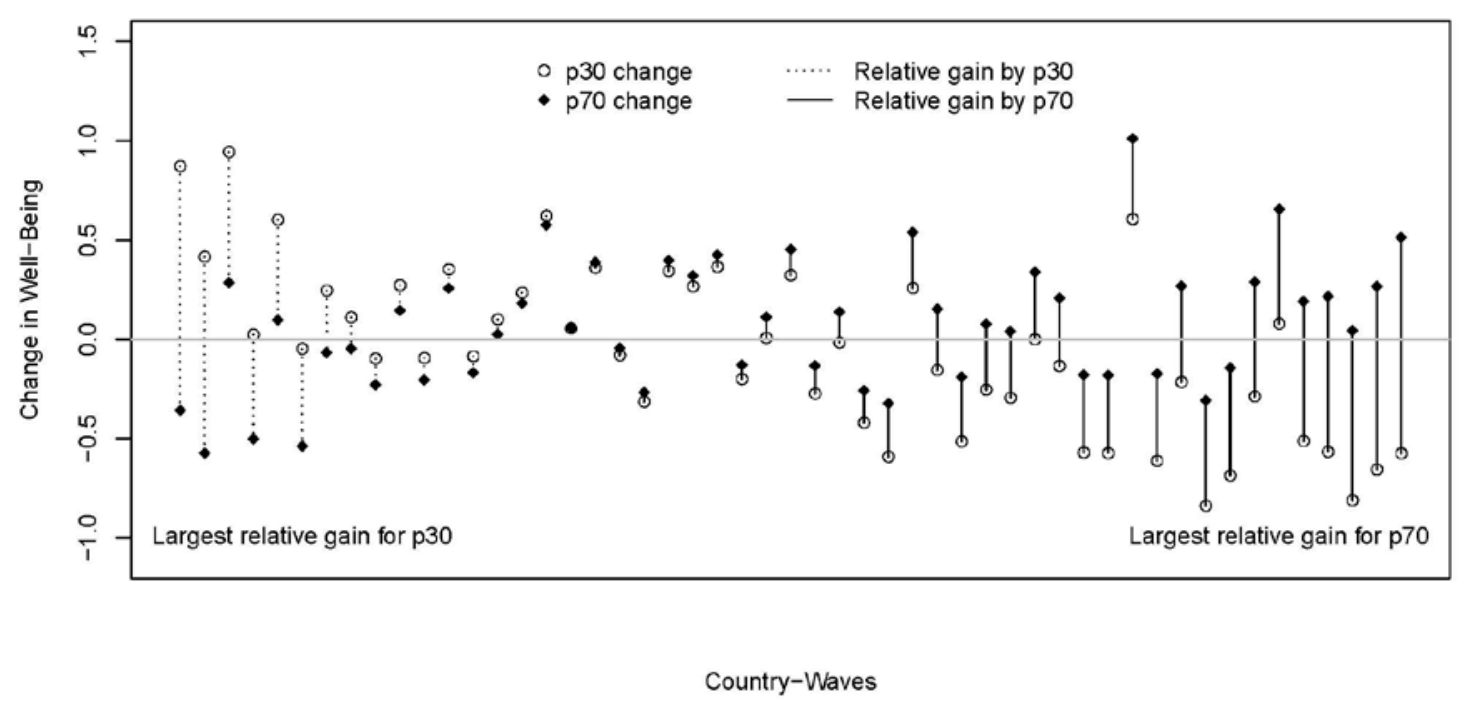

Notes: The $Y$ axis indicates the magnitude of change in well-being from the previous period. Figures above the line are positive and below the line negative changes. The solid diamonds indicate change in well-being of people with incomes at p70 and above. The circles indicate changes in well-being of people with incomes at p30 and below over the same period. Each line indicates changes in one country over one time period.

Source: World Values Survey. 
TABLE ONE: The material determinants of inequality in well-being in OECD countries

\begin{tabular}{|l|l|l|l|l}
\hline & Model 1 & Model 2 & Model 3 & Model 4 \\
\hline (Intercept) & $0.90^{*}$ & $0.82 *$ & $0.81^{*}$ & $0.58^{*}$ \\
& 0.08 & 0.07 & 0.09 & 0.09 \\
\hline $\begin{array}{l}\text { GDP/capita } \\
\text { (00000s) }\end{array}$ & 0.14 & $0.23 *$ & 0.22 & 0.12 \\
\hline Unemployment & 0.1 & 0.11 & 0.13 & 0.09 \\
Rate & 0.04 & 0.27 & & \\
\hline Inequality & $0.37 *$ & 0.39 & & \\
(Prefisc gini) & 0.15 & 0.17 & $0.52 *$ & $1.31^{*}$ \\
\hline Social spending & & & 0.21 & 0.24 \\
(00000s) & & & -0.27 & \\
& & & $0.79)$ & \\
\hline Redistributive & & & & $-0.93 *$ \\
Effort & & & -0.02 & -0.01 \\
\hline Mediterranean & & -0.01 & 0.02 & 0.02 \\
\hline Social & & 0.02 & 0.04 & $0.12 *$ \\
Democratic & & 0.03 & 0.03 & 0.03 \\
\hline Continental & & 0.02 & $0.05 *$ & $0.09 *$ \\
\hline $\mathrm{N}$ & & $0.05 *$ & 0.02 & 0.02 \\
\hline $\mathrm{R}^{2}$ & 52 & 0.02 & 52 & 52 \\
\hline adj. $\mathrm{R}^{2}$ & 0.09 & 52 & 0.35 & 0.53 \\
\hline Resid. sd & 0.05 & 0.04 & 0.04 & \\
\hline
\end{tabular}

Note: Standard errors in italics below the coefficient. Levels of statistical significance indicated as follows: $*=.10, * *=.05, * * *=.001$. The omitted type of welfare state is Liberal. 
TABLE TWO: Individual-level and country-level determinants of individual well-being. Hierarchical linear models

\begin{tabular}{|c|c|c|c|c|c|}
\hline & Model 1 & Model 2 & Model 3 & Model 4 & Model 5 \\
\hline \multicolumn{6}{|c|}{ Country-Level Variables } \\
\hline $\begin{array}{l}\text { Rate of } \\
\text { Unemplmt }\end{array}$ & $\begin{array}{l}7.97 * * \\
3.34\end{array}$ & & & $\begin{array}{l}2.63 \\
3.71\end{array}$ & \\
\hline GDP/capita (000s) & $\begin{array}{l}0.02^{* *} \\
0.01\end{array}$ & & & $\begin{array}{l}0.02 \\
0.01\end{array}$ & \\
\hline \begin{tabular}{|l} 
Income \\
Inequality
\end{tabular} & $\begin{array}{l}-5.04 * * \\
1.65\end{array}$ & & & $\begin{array}{l}-3.21 * \\
1.79\end{array}$ & $\begin{array}{l}-4.28 * * \\
1.71\end{array}$ \\
\hline $\begin{array}{l}\text { Redistributive } \\
\text { Effort }\end{array}$ & & & & & $\begin{array}{l}1.53^{*} \\
0.68\end{array}$ \\
\hline $\begin{array}{l}\text { Level of } \\
\text { Assoc Mbrshp }\end{array}$ & & & $\begin{array}{l}0.19 * \\
0.08\end{array}$ & & \\
\hline $\begin{array}{l}\text { Trade Union } \\
\text { Density }\end{array}$ & & & & $\begin{array}{l}0.99 * \\
0.41\end{array}$ & \\
\hline \multicolumn{6}{|c|}{ Individual-Level Variables } \\
\hline (Intercept) & $\begin{array}{l}8.21 * * \\
0.79\end{array}$ & $\begin{array}{l}7.13 * * \\
0.15\end{array}$ & $\begin{array}{l}7.27 * * \\
0.18\end{array}$ & $\begin{array}{l}7.77 * * \\
0.78\end{array}$ & $\begin{array}{l}8.65^{* *} \\
0.74\end{array}$ \\
\hline $\begin{array}{l}\text { Association } \\
\text { Membership }\end{array}$ & $\begin{array}{l}0.17 * * \\
0.02\end{array}$ & $\begin{array}{l}0.07 * * \\
0.01\end{array}$ & $\begin{array}{l}0.15 * * \\
0.01\end{array}$ & & $\begin{array}{l}0.17^{* *} \\
0.02\end{array}$ \\
\hline $\begin{array}{l}\text { Ties } \\
\text { to Family }\end{array}$ & & $\begin{array}{l}0.5^{* *} \\
0.03\end{array}$ & & & \\
\hline Ties to Friends & & $\begin{array}{l}0.22 * * \\
0.02\end{array}$ & & & \\
\hline $\begin{array}{l}\text { AM:Income } \\
\text { Interaction }\end{array}$ & $\begin{array}{l}-0.01^{* *} \\
0\end{array}$ & & $\begin{array}{l}-0.01 * * \\
0\end{array}$ & & $\begin{array}{l}-0.01 * * \\
0\end{array}$ \\
\hline Years of Education & $\begin{array}{l}0.01 \\
0.02\end{array}$ & $\begin{array}{r}-0.01 \\
0.01\end{array}$ & $\begin{array}{r}-0.01 \\
0.01\end{array}$ & 0.01 & 0.01 \\
\hline $\begin{array}{l}\text { Years of. education } \\
\wedge 2\end{array}$ & $\begin{array}{l}0 \\
0\end{array}$ & 0 & $\begin{array}{l}0 \\
0\end{array}$ & $\begin{array}{l}0 \\
0\end{array}$ & $\begin{array}{l}0 \\
0\end{array}$ \\
\hline Unemployed & $\begin{array}{l}-0.73^{* *} \\
0.06\end{array}$ & $\begin{array}{l}-0.78^{* *} \\
0.05\end{array}$ & $\begin{array}{l}-0.79 * * \\
0.05\end{array}$ & $\begin{array}{l}-0.82^{* *} \\
0.05\end{array}$ & $\begin{array}{l}-0.77^{* *} \\
0.05\end{array}$ \\
\hline Income & $\begin{array}{l}0.14 * * \\
0.01\end{array}$ & $\begin{array}{l}0.1^{* *} \\
0\end{array}$ & $\begin{array}{l}0.12 * * \\
0\end{array}$ & $\begin{array}{l}0.12 * * \\
0\end{array}$ & $\begin{array}{l}0.13^{* *} \\
0.01\end{array}$ \\
\hline Female & $\begin{array}{l}0.02 * * \\
0.02\end{array}$ & $\begin{array}{r}-0.03 \\
0.02\end{array}$ & $\begin{array}{l}0.01 \\
0.02\end{array}$ & $\begin{array}{l}0.03 \\
0.02\end{array}$ & $\begin{array}{l}0.01 \\
0.02\end{array}$ \\
\hline Age & $\begin{array}{l}-0.03^{* *} \\
0.0\end{array}$ & $\begin{array}{l}-0.03 * * \\
0\end{array}$ & $\begin{array}{l}-0.03 * * \\
0\end{array}$ & $\begin{array}{l}-0.03^{* *} \\
0\end{array}$ & $\begin{array}{l}-0.03 \\
0\end{array}$ \\
\hline Age $^{\wedge} 2$ & $\begin{array}{l}0^{* *} \\
0\end{array}$ & $\begin{array}{l}0 * * \\
0\end{array}$ & $\begin{array}{l}0^{* *} \\
0\end{array}$ & $\begin{array}{l}0^{* *} \\
0\end{array}$ & $\begin{array}{l}0^{* *} \\
0\end{array}$ \\
\hline $\mathrm{N}$ obs & 26966 & 38411 & 38874 & 31964 & 29044 \\
\hline $\mathrm{N}$ groups & 40 & 54 & 55 & 48 & 41 \\
\hline AIC & 107479 & 152724 & 155279 & 127882 & 116107 \\
\hline BIC & 107684 & 152920 & 155476 & 128083 & 116306 \\
\hline
\end{tabular}

Notes: Intercepts vary by country-wave. Standard errors are in italics below the coefficient. Statistical significance indicated as follows: $*=.05, * *=.01$. 
TABLE THREE: The relationship between social class and social connectedness

\section{Ties to Friends/Family}

(Waves 2 \& 5)

Index Score

5.33

5.25

Workers (C1)

\section{Skilled Manual}

Workers (C2)

5.16

\section{Membership in} Associations

(Waves 2 \& 5)

Mean Number

2.2

2.09

35

32

5.09

\section{Ever Feel}

Lonely

(Wave 1)

$\%$ Frequently or Sometimes

28

31

1.8

33

41

Unskilled, Semi-Skilled

Manual (DE)

Source: World Values Survey.

Notes: Higher values on the family/friends index indicate ties to family/friends are more important to the person; for details see Barnes et al. 2010. The indicator 'spend time socially' averages responses from each class to questions asking if respondents ever spend time with colleagues from work or with people at sport, cultural or communal organizations. 
TABLE FOUR: The impact of inequality in well-being on hostility to immigrants

\begin{tabular}{|l|l|l|l|l|l|}
\hline & Model 1 & & Model 2 & & Model 3 \\
\hline (Intercept) & -0.23 & & -0.21 & & -0.21 \\
& 0.15 & & 0.15 & & 0.15 \\
\hline GDP per Capita & -0.06 & & -0.01 & -0.01 \\
(00000s) & 0.10 & & 0.01 & 0.01 \\
\hline Inequality in & $-0.32^{*}$ & & $-0.27^{*}$ & & $-0.27 *$ \\
Well-Being & 0.14 & & 0.13 & & 0.13 \\
\hline Value of & & & & -0.00 \\
Tolerance & & & & 0.05 \\
\hline Mediterranean & & & 0.00 & & 0.00 \\
& & & $(0.02)$ & & 0.02 \\
\hline Social & & & 0.00 & & 0.00 \\
Democratic & & & 0.02 & & 0.02 \\
\hline Continental & & & 0.03 & & 0.03 \\
& & & 0.02 & & 0.02 \\
\hline $\mathrm{N}$ & 66 & & 66 & & 66 \\
\hline $\mathrm{R}^{2}$ & & & & & \\
\hline
\end{tabular}

Notes: Standard errors in parentheses. Levels of statistical significance indicated as follows: $*=.10, * *=.05$ 


\section{References}

Adger, W. Neil. 2000. “Social and Ecological Resilience: Are they Related?” Progress in Human Geography 24(3): 347-64/

Alesina, Alberto, Rafael DiTella and Robert MacCulloch. 2004. "Inequality and Happiness: Are Europeans and Americans Different?” Journal of Public Economics 88(9-10): 2009-42.

Andersen, Robert and Tina Fetner. 2008. "Economic Inequality and Intolerance: Attitudes toward Homosexuality in 35 Democracies,” American Journal of Political Science 52,4: 942-58.

Antràs, Pol, Luis Garicano and Esteban Rossi-Hansberg. 2006. "Offsoring in a Knowledge Economy,” Quarterly Journal of Economics.

Autor, D., L. Katz and M. Kearny. 2005. "Trends in U.S. Wage Inequality: Re-Assessing the Revisionists.” Working Paper No. 11627. Cambridge, MA.: National Bureau of Economic Research.

Baccaro, Lucio and Chris Howell. 2011. "A Common Neoliberal Trajectory: The Transformation of Industrial Relations in Advanced Capitalism,” Politics and Society 39(4): 521-63.

Barnes, Lucy, Peter A. Hall and Rosemary CR Taylor. 2010. “The Social Sources of the Health Gradient: A Cross-National Analysis.” Manuscript.

Bates, Robert. H. 1981. States and Markets in Tropical Africa: The Political Basis of Agricultural Policy. Berkeley: University of California Press.

Beer, Samuel H. 1974. Patterns of Government. New York: Random House.

Beer, Samuel H. 1982. Britain Against Itself. New York : Norton.

Berkman, Lisa and Thomas Glass. 2000. "Social Integration, Social Networks, Social Support and Health.” In. 2000 Social Epidemiology edited by Lisa Berkman and Ichiro Kawachi. New York: Oxford University Press: 137-74.

Berkman, Lisa, Thomas Glass, Ian Brissett and Teresa E. Seeman. 2000. "From Social Integration to Health: Durkheim in the New Millenium,” Social Science and Medicine 51: 84357.

Blanchflower, David G. and Andrew J. Oswald. 2004. "Well-Being Over Time in Britain and the USA,” Journal of Public Economics 88: 1359-1386.

Blyth, Mark M.. 2002. Great Transformations: Economic Ideas and Political Change in the Twentieth Century. New York: Cambridge University Press.

Boltanski, Luc and Eve Chiapello. 1999. Le Nouvel Esprit du Capitalisme. Paris : Gallimard.

Bouchard, Gérard. 2003. Raison et Contradiction : Le Mythe au Secours de la Pensée. Québec : Éditions Nota bene/Cefan. 
Card, D. and J. Di Nardo. 2002. "Skill-Biased Technological Change and Rising Wage

Inequality: Some Problems and Puzzles,” Journal of Labor Economics 20(4): 733-83.

Cornell, Stephen and Joseph P. Kalt. 2000. "Where’s the Glue? Institutional and Cultural Foundations of American Indian Economic Development,” Journal of Socio-Economics 29: 44370 .

Crouch, Colin and Alessandro Pizzorno, eds. 1978. The Resurgence of Class Conflict in Western Europe. London: Macmillan.

Crystal, Alec. 1979. Controversies in British Macroeconomics. London: Philip Alan.

Cusack, Thomas and Lutz Englehardt. 2002. The PGL File Collection: Computer File. Berlin: Wissenschaftszentrum Berlin für Sozialforschung.

Cuthbertson, Keith. 2000. Macroeconomic Policy: New Cambridge, Keynesian and Monetarist Controversies. London: Halsted Press.

Dalton, Russell, Scott Flanagan and Paul Beck, eds. 1984. Electoral Change in Advanced Industrial Democracies. Princeton: Princeton University Press.

Diener, E., E.M. Suh, R.E. Lucas and H.E. Smith. 1999. "Subjective Well-Being: Three Decades of Progress,” Psychological Bulletin 125: 276-302.

Di Tella, Rafael, John Haisken-De-New and Robert MacCulloch 2010. "Happiness Adapatation to Income and to Status in an Individual Panel," Journal of Economic Behavior and Organization 76: 834.-52.

Easterlin, Robert. 1974. “Does Economic Growth Improve the Human Lot?” In Nations and Households in Economic Growth: Essays in Honor of Moses Abramovitz, edited by Paul A. David and Melvin W. Reder. New York: Academic Press, pp. 89-125.

Easterlin, Robert. 1995. "Will Raising the Incomes of All Increase the Happiness of All?” Journal of Economic Behavior and Organization 27: 35-47.

Eichengreen, Barry. 2007. The European Economy since 1945: Coordinated Capitalism and Beyond. Princeton: Princeton University Press.

Esping-Andersen, Gösta. 1990. Three Worlds of Welfare Capitalism. Princeton: Princeton University Press.

Esping-Andersen, Gösta. 1999. Social Foundations of Post-Industrial Economies. Oxford: Oxford University Press.

Flavin, Patrick, Alexander C. Pacek and Benjamin Radcliff. 2010. "Labor Unions and Life Satisfaction: Evidence from New Data,” Social Indicators Research 98(3): 435-49.

Flavin, Patrick, Alexander C. Pacek and Benjamin Radcliff. 2011. "State Intervention and Subjective Well-Being in Advanced Industrial Democracies,” Politics \& Policy 39(2): 251-69. 
Folke, Carl. 2006. "Resilience: The Emergence of a Perspective for Socioal-Ecological Systems Analyses,” Global Environmental Change 16: 253-67.

Freeman, Richard and James B. Medoff. 1984. What Do Unions Do? New York: Basic Books.

Gamble, Andrew. 1988. The Free Economy and the Strong State: The Politics of Thatcherism. Basingstoke: Palgrave-Macmillan.

Glyn, Andrew. 2006. Capitalism Unleashed: Finance, Globalization and Welfare. Oxford: Oxford University Press.

Goldstein, Judith and Robert Keohane. 1993. “Ideas and Foreign Policy: An Analytical Framework" in Ideas and Foreign Policy, edited by Judith Goldstein and Robert Keohane. Ithaca: Cornell University Press: 3-30.

Gottschalk, Peter and Tim Smeeding. 1997. "Cross-National Comparisons of Earnings and Income Inequality,” Journal of Economic Literature 35(6): 633-87.

Habermas, Jürgen. 1985. The Theory of Communicative Action. Boston: Beacon.

Hacker, Jacob S. 2004. "Privatizing Risk Without Privatizing the Welfare State: The Hidden Politics of Social Policy Retrenchment in the United States," American Political Science Review 98(2): 243-60

Hacker, Jacob S., Gregory A. Huber, Philipp Rehm, Mark Schlesinger and Rob Valletta. 2010. Economic Security at Risk: Finding from the Economic Security Index. New York: Rockefeller Foundation.

Hacker, Jacob and Paul Pierson. 2010. Winner Take-All Politics: How Washington Made the Rich Richer and Turned its Back on the Middle Class. New York: Simon and Schuster.

Hall, Peter A. 1986. Governing the Economy: The Politics of State Intervention in Britain and France. Oxford: Polity Press.

Hall, Peter A. 1989. ed. The Political Power of Economic Ideas: Keynesianism across Nations. Princeton: Princeton University Press.

Hall, Peter A. 1993. "Policy Paradigms, Social Learning and the State: The Case of Economic Policy-Making in Britain,” Comparative Politics (April): 275-96.

Hall, Peter A. 2010. “Samuel H. Beer and the Possibilities of Politics,” British Politics

Hall, Peter A. and Michèle Lamont, eds. 2009. Successful Societies: How Institutions and Culture Affect Health. New York: Cambridge University Press.

Hall, Peter A. and David Soskice. 2001. Varieties of Capitalism: The Institutional Foundations of Comparative Advantage. Oxford: Oxford University Press.

Hall, Peter A. and Kathleen Thelen. 2009. "Institutional Change in Varieties of Capitalism,” Socio-Economic Review 7(1): 7-34. 
Hann, Chris. 1993, ed. Socialism: Ideals, Ideologies and Local Practics. London: Routledge.

Harjes, Thomas. 2007. “Globalization and Income Inequality: A European Perspective.” IMF Working Paper. 07/160. Washington: International Monetary Fund.

Held, David. 2006. Models of Democracy: Cambridge: Polity.

Helliwell, John. 2008. “Life Satisfaction and Quality of Development.” Working Paper 14507. National Bureau of Economic Research, Cambridge MA.

Helliwell, John and Christopher P. Barrington-Leigh. 2010. "Measuring and Understanding Subjective Well-Being.” Working Paper 15887. National Bureau of Economic Research, Cambridge MA.

Helliwell, John, Haifang Huang and Anthony Harris. 2010. "International Differences in the Determinants of Life Satisfaction.” Mss.

Hirsch, Barry T. 2003. What Do Unions Do for Economic Performance? Discussion Paper No. 892. Bonn: IZA.

Hochschild, Arlie Russell. 2003. The Commercialization of Intimate Life: Notes from Home and Work. Berkeley: University of California Press.

Hochschild, Jennifer. 1981. What's Fair: American Beliefs about Distributive Justice. Cambridge, MA: Harvard University Press.

Huber, Evelyne and John D. Stephens. 2001. Development and Crisis of the Welfare State. Chicago: University of Chicago Press.

Inglehart, Ronald. 1990. Culture Shift in Advanced Industrial Society. Princeton: Princeton University Press.

International Social Survey Program, Consolidated Role of Government Surveys I to IV.

Iversen, Torben. 2006. “Class Politics is Dead! Long Live Class Politics! A Political Economy Perspective on the New Partisan Politics,” APSA-CP Newsletter 17(20): 1-6.

Iversen, Torben and Thomas Cusack. 2000. "The Causes of Welfare State Expansion:

Deindustrialization or Globalization,” World Politics, 52: 313-49.

Iversen, Torben and David Soskice. 2006. "Electoral Institutions and the Politics of Coalitions: Why Some Democracies Redistribute More than Others,” American Political Science Review 100 (2): 165-181.

Kenworthy, Lane and Jonas Pontusson. 2005. "Rising Inequality and the Politics of Redistribution in Affluent Countries,” Perspectives on Politics 3, 3 (September): 449-471.

King, Desmond. 1987. The New Right: Politics, Markets and Citizenship. Basingstoke: PalgraveMacmillan. 
Kitschelt, Herbert. 1997. The Radical Right in Western Europe. Ann Arbor: University of Michigan Press.

Krieger, Joel. 1986. Reagan, Thatcher and the Politics of Decline. New York: Oxford University Press.

Lamont, Michèle. 2000. The Dignity of Working Men: Morality and the Boundaries of Race, Class and Immigration. Cambridge, MA: Harvard University Press.

Lane, Robert E. 1972. Political Man. New York: Basic Books..

Leamer, Edward. 1996. "Wage Inequality from International Competition and Technological Change: Theory and Country Experience,” American Economic Review 86(2): 309-14.

Levey, Hilary. 2010. "Raising Middle Class Children in the Competitive Culture of the United States: Parenting and Competitive Children's Activities.” Forthcoming in Dilemmas of the Middle Class around the World, edited by Katherine S. Newman.

Link Bruce G. and Jo C. Phelan. 1995. "Social conditions as fundamental causes of disease.” Journal of Health and Social Behavior: 80-94.

Lipset, Seymour Martin. 1964. “The Changing Class Structure and Contemporary European Politics,” Daedalus 93(1) (Winter): 271-303.

Lubbers, M. and P. Scheepers. 2000. "Individual and Contextual Characteristics of the German extreme right vote in the 1990s.” European Journal of Political Research 38 (1): 63-94.

Mayntz, Renate and Fritz Scharpf. 1987 "Politische Steuerung und gesellschaftliche Steuerungsprobleme. Anmerkungen zu einem theoretischen Paradigma.“ In Jahrbuch zur Staatsund Verwaltungswissenschaft, edited by T. Ellwein, J.J. Hesse, R. Mayntz, and F.W. Scharpf. Baden-Baden: Nomos, 89-110

McGraw, Sean. Forthcoming. Democracy's Choices:: Irish Political Parties and the Constraining of the Political Arena. New York: Cambridge University Press.

McNamara, Kathleen. 1998. The Currency of Ideas. Ithaca: Cornell University Press.

Nussbaum, Martha. 2001. Women and Human Development: The Capabilities Approach. Cambridge: Cambridge University Press.

Offe, Claus. 1983. "Competitive Party Democracy and the Keynesian Welfare State: Factors of Sability and Disorganization,” Policy Sciences, 15: 225-46.

OECD. 2008. Growing Unequal? Income Distribution and Poverty in OECD Countries. Paris: OECD.

OECD. 2009. Society at a Glance: Social Indicators. Paris: OECD.

Oswald, Andrew J. 1985. “The Economic Theory of Trade Unions,” Scandinavian Journal of Economics 87(2): 160-93. 
Pacek, Alexander and Benjamin Radcliff. 2008. "Assessing the Welfare State: The Politics of Happiness,” Perspectives on Politics 6(2): 267-77.

Pinto, Sanjay and Jason Beckfield. 2011. "Organized Labor in Europe 1960-2006: Common Decline, Continuing Differences,” Research in the Sociology of Work 22: 153-79.

Polanyi, Karl. 1944. The Great Transformation: Political and Economic Origins of our Time. Boston: Beacon Press.

Pontusson, Jonas. 2005. Inequality and Prosperity: Social Europe versus Liberal America. New York: Cornell University Press.

Pontusson, Jonas and David Rueda. 2009. "The Politics of Inequality: Voter Mobilization and Left Parties in Advanced Industrial States,” Comparative Political Studies.

Prasad, Monica. 2006. The Politics of Free Markets: The Rise of Neoliberal Economic Policies in Britain, France, Germany and the United States. Chicago: University of Chicago Press.

Putnam, Robert. 2001. Bowling Alone: The Collapse and Revival of American Community. New York: Simon and Schuster.

Radcliff, Benjamin. 2005. "Class Organization and Subjective Well-Being: A Cross-National Analysis,” Social Forces 84(1): 513-30.

Rueda. David. 2007. Social Democracy Inside Out: Government Partisanship, Insiders, and Outsiders in Industrialized Democracies. Oxford: Oxford University Press.

Sampson, Robert J., Jeffrey D. Morenoff, and Thomas Gannon-Rowley. 2002. “Assessing Neighborhood Effects: Social Processes and New Directions in Research”. Annual Review of Sociology 28:443-478.

Sauder, Michael and Wendy Espeland. 2009. “The Discipline of Rankings: Tight Coupling and Organizational Change,” American Journal of Sociology 74(1):

Scheepers, Peer, Manfred Te Grotenhuis and John Gelissen. 2002. "Welfare States and Dimensions of Social Capital: Cross-National Comparisons of Social Contacts in European Countries,“ European Societies 4(2): 185-207.

Schoon, Ingrid. 2006. Risk and Resilience: Adaptations in Changing Times. Cambridge: Cambridge University Press.

Sen, Amartya. 1999. Development as Freedom. New York: Alfred A. Knopf.

Sennett, Richard. 2006. The Culture of the New Capitalism. New Haven: Yale University Press.

Stevenson, Betsey and Justin Wolfers. 2009. “The Paradox of Declining Female Unhappiness,” American Economic Journal: Economic Policy 1,2: 190-225.

Stiglitz, Joseph P., Amartya Sen and Jean-Paul Fitoussi. 2009. Report of the Commission on the Measurement of Economic Performance and Social Progress. Paris. 
Streeck, Wolfgang. 2009. Re-Forming Capitalism: Institutional Change in the German Political Economy Oxford: Oxford University Press.

Suh, Eunkook, Ed Diener and Frank Fujita. 1996. "Events and Subjective Well-Being: Only Recent Events Matter,“ Journal of Personality and Social Psychology 70(5): 1091-1102.

Swank, Duane. 2002. Global Capital, Political Institutions and Policy Change in Developed Welfare States. New York: Cambridge University Press.

Swank, Duane and Hans-Georg Betz. 2002. "Globalization, the Welfare State and Right-Wing Populism in Western Europe,” Socio-Economic Review 1(2): 215-45.

Tanzi, Vito. 2005. "The Economic Role of the State in the $21^{\text {st }}$ Century,” Cato Journal 25(3): 617-38.

Taylor-Gooby, Peter, ed, 2004. New Risks, New Welfare: The Transformation of the European Welfare State. Oxford: Oxford University Press.

Ungar, Michael. 2008. “Resilience across Cultures,” British Journal of Social Work 38: 218-35.

Van der Brug, Wouter, Meindert Fennema and Jean Tille. 2005. "Why Some Anti-Immigrant Parties Fail and Others Succeed: A Two-Step Model of Aggregate Electoral Support,“ Comparative Political Studies 38(5): 537-73.

Veenhoven, Ruut. 1996. “Developments in Satisfaction Research,” Social Indicators Research 37: 1-46.

Vogel, Steven. K. 1998. Freer Markets, More Rules: Regulatory Reform in Advanced Industrial Welfare States. Ithaca: Cornell University Press.

Wedel, Jan. 1986. The Private Poland: An Anthropologist's Look at Everyday Life. Warsaw: Facts on File.

Wood, Adrian. 1994. North-South Trade, Employment and Inequality: Changing Fortunes in a Skill-Driven World. Oxford: Oxford University Press.

Wood, Stewart. 2001. "Employer Preferences, State Power and Labor Market Policy and Germany and Britain" in Varieties of Capitalism, edited by Peter A. Hall and David Soskice. Oxford: Oxford University Press: 


\section{Notes}

We are grateful to Peter Gourevitch for inspiration for this chapter and to Jason Beckfield, Jim Ennis, Robert Fishman, John Helliwell, Lane Kenworthy, Will Kymlicka, Martin Schröder, Rosemary Taylor and colleagues in the Successful Societies Program for helpful comments. Roberto Foa provided research assistance.

$1 \quad$ The dotted line shows the relative balance in these legislatures between parties on the political left and right as classified by experts. We are grateful to Torben Iversen for sharing this data.

2 The high income group is people with incomes at the $70^{\text {th }}$ percentile and above; low income is at the $30^{\text {th }}$ percentile and below, and the middle income group is those in between.

3 It remains an open question how profound or pervasive this shift in views has been. There has been no analogous increase, for instance, in the numbers deeming it justifiable to cheat on their taxes.

$4 \quad$ The countries included in the statistics given in Figure Five include: Argentina, Australia, Brazil, Bulgaria, Canada, Chile, China, Finland, Germany, India, Italy, Japan, South Korea, Mexico, the Netherlands, Poland, Romania, Russia, Slovenia, Sweden, the UK and the US.

5 The relevant question asks 'All things considered, how satisfied are you with your life as a whole these days?' to which a response is given ranging from 1 (completely dissatisfied) to 10 (completely satisfied).

$6 \quad$ To secure comparability with our calculations for the change in average well-being, for this figure, GDP per capita is averaged across countries unweighted for the size of their population.

$7 \quad$ This time-series data presents the usual problems for causal inference. For instance, inequality in the UK in 2005 is not independent of inequality in 2000. Because we have a small panel, we cannot isolate statistically significant effects when a lagged-dependent variable is included, although the point estimates retain the signs indicated in Table One. Thus, the coefficients should be interpreted with caution. Using panel-corrected standard errors to allow for panel heteroskedasticity, however, tends to reduce the standard errors and leave all substantive interpretations intact.

$8 \quad$ Note, however, that higher levels of unemployment depress average levels of well-being, as indicated in the results of estimations of a hierarchical linear model reported in model 1 of Table Two. Higher levels of income inequality also have a large effect on average well-being. The movement from the highest to the lowest levels of income inequality in our sample is associated with an improvement in average well-being equivalent to that obtained by increasing per capita income by about $\$ 50,000$.

$9 \quad$ An important literature in psychology argues that subjective well-being is also mediated by various features of personality. Longitudinal studies from this perspective find that subjective well-being is conditioned for some time by life events such as unemployment (Suh et al. 1996; Clark et al. 2008). Personality is unlikely to explain the variations in well-being across time in the large social groups in which we are interested. However, to control for it, in estimations not reported here, we have included a variable measuring 'self-mastery', widely-seen as a dimension of personality linked to well-being. We find that self-mastery has a statistically-significant effect on well-being at the individual level and including it attenuates the size of our point estimates on ties to family, friends and associational memberships, but the latter continue to have a statistically-significant impact on well-being in terms substantively similar to those reported here.

10 Conversely, low income has more damaging effects on the well-being of people with few social connections than on those who are well-connected. 
11

The results are similar using either the OECD measure for trade union density or a measure derived from the WVS samples. 